\title{
Effect of Exposure to Different Doses of Cell Phone-Electromagnetic Waves on the Hippocampus and Testis of Adult Albino Rats: A Histological Study
}

\author{
Bataa MA El-Kafoury', Ghada Galal Hamam ${ }^{2}$ and Samar F Ezzat ${ }^{2}$ \\ ${ }^{1}$ Physiology Department, ${ }^{2}$ Department of Histology and Cell Biology, Faculty of Medicine, \\ Ain Shams University, Cairo, Egypt
}

\begin{abstract}
Introduction: Every new technological product brings certain disadvantages threatening human health. Electromagnetic fields (EMF) emitted from cell phones may exert a detrimental influence on human health and may affect man`s cognitive and reproductive systems. Mobile phones are carried mainly near the head during talking and they are also kept in trousers pockets in close distance to testis.

Aim: To study the effect of single or multiple exposure to different doses of EMF from mobile phone on the structure of hippocampus and testis in adult albino Wistar rats

Materials and Methods: Thirty adult male albino Wistar rats were divided into three equal groups. Group I (control), group II (single mobile exposure giving 900Hz) and group III (multiple mobile exposure giving 2700HZ). Rats were exposed to EMW for 120 minutes/day, 6 days per week for ten weeks. Animals were sacrificed 24 hours after the last exposure. Hippocampus and testis were harvested form all rats. They were subjected to proper histological techniques. Semen analysis, morphometric and statistical studies were also done.

Results: In single exposure group, degeneration of some pyramidal and granule cells of the hippocampus were noticed. Vacuolations were also seen between spermatogenic cells with some abnormalities of sperm structure. While in multiple exposure group, apparent increase number of degenerated neurons and significant decrease in thickness of pyramidal and granule layers of hippocampus were noticed. Testis showed intercellular vacuolations, significant decrease in thickness of germinal epithelium and seminiferous tubules and a significant increase in mean area percentage of collagen fibers and caspase-3 reaction. Many sperm abnormalities were also detected in semen analysis.

Conclusions: Exposure to EMF causes significant changes in the structure of hippocampus and testis in a dose dependent manner.
\end{abstract}

Received: 08 June 2019, Accepted: 16 June 2019

Key Words: Electromagnetic waves, hippocampus, histology, mobile phones, testis.

Corresponding Author: Ghada Galal Hamam, PhD, Histology and Cell Biology Department, Faculty of Medicine, Ain Shams University, Cairo, Egypt, Tel.: +20 1003960601, E-mail: ghada.hamam@yahoo.com

ISSN: 1110-0559, Vol. 42, No. 4

\section{INTRODUCTION}

Developments in technology have simplified human life. Nonionizing electromagnetic radiation is produced from energy sources, as power lines, mobile phones and common electrical devices ${ }^{[1-3]}$. This type of radiation differs from ionizing radiation, as gamma rays, $\mathrm{X}$-rays, and ultraviolet light, which exhibit high-frequency waves that liberate electrons from molecules ${ }^{[4]}$. Although nonionizing radiation has a lower frequency and is generally considered safe, accumulating evidence suggests that some types of nonionizing electromagnetic radiation have enough energy to harm living tissues ${ }^{[1-3]}$. Cellular phones are defined as devices emitting radiofrequency electromagnetic fields (EMF). These waves transmit signals from the cellular phone to the base stations and antennas. The frequency of such waves ranges from $800-2,200 \mathrm{MHz}$. However, our bodies can act as antennas that absorb these waves ${ }^{[5]}$. According to one report, $90 \%$ of adolescents have a mobile phone and about $40 \%$ of them are considered as heavy mobile phone users, therefore, this has raised public concerns about the potential health hazard of radio frequency fields on adolescents ${ }^{[3]}$.

The hippocampus is involved in emotional behavior related to pain, declarative memory and stress ${ }^{[6]}$. In adults, constant multi-tasking on cell phone devices was reported to impair adolescents' cognitive performance $\mathrm{e}^{[7]}$. Cognition is a core function of the cerebrum ${ }^{[8]}$. Dentate gyrus is an important part of the hippocampal formation of the limbic system, which is concerned with cognition and memory consolidation $^{[9]}$.

The prevalence of male infertility at the reproductive age has been estimated to be up to $7-8 \%$, and there has been a tendency to increase in recent decades. Idiopathic male infertility originates from decreased sperm quality with no organic, genetic, or endocrine alterations in the genital tract ${ }^{[10]}$. Some studies have reported that EMW can have adverse effects on reproduction and fertilizing 
potential of spermatozoa, while, several studies showed that exposure to EMF did not induce any adverse effects on the reproductive capacity ${ }^{[1]}$.

The head receives much more radiofrequency energy because the mobile phone is usually held at the ear during communication. Whether radiofrequency exposure results in brain dysfunction, has become a major topic of investigation $^{[3]}$. Testes are also located at a close distance from mobile phones carried in back pocket, front pocket or on waistband (which is always on because of its Internetbased communication). This causes testis to be exposed to EMF emitted by mobile phones for long hours during the day $^{[10,11]}$.

\section{AIM OF THE WORK}

This study was designed to study the effects of different doses of whole-body exposure to cell phone-EMF on the structure of hippocampus and testis in adult male albino Wistar rats.

\section{MATERIALS AND METHODS}

\section{A-Animals and diet}

The study was performed on 30 Wistar adult male rats. Their age ranged from 3-4 months and their weight was about 170 gram. Animals were housed in plastic cages with proper conditions of light, ventilation, temperature, humidity and free access to food and water. The experiment was conducted in the conducted in the Medical Research Center, Faculty of Medicine, Faculty of Medicine, AinShams University. Animal manipulations were performed with maximal care and hygiene. Animal procedures were carried out according to the guideline of animal care and the scientific research ethical committee of the Faculty of Medicine, Ain Shams University.

\section{B-Experimental protocol}

Animals were kept for one week before the beginning of the experiment for acclimatization, then they were randomly divided into three groups ten rats each:

Group I (control group): was divided into two equal subgroups.

Subgroup Ia: (Negative control): animals were maintained in their cages without any interference.

Subgroup Ib: (Sham group): animals were kept in their cage with cellular phones placed beneath the cages with the phones turned off.

Group II (Single exposure group): single cell phoneemitted EMF exposure (one cell phone $990 \mathrm{~Hz}$ ).

Group III (Multiple exposure group): multiple cell phone-emitted EMF exposure (three cell phone $990 \mathrm{~Hz}$ each)

\section{C-Mobile phones}

A 2 G mobile phones were used in this experiment. A radiofrequency field was emitted by $900-1800 \mathrm{MHz}$ frequency band (Global System for Mobile Communication (GSM)) mobile phone. The GSM cell phones operated with microwave carrier frequencies in the $\mathrm{GHz}$ range $(850-1900 \mathrm{MHz})^{[12]}$.

\section{D-Exposure Technique}

Animals of group II and III, were kept in special plastic cages, cell phones were placed under the cage by distance $0.5 \mathrm{~cm}$. This distance allowed the mice to move freely and to avoid direct thermal injury ${ }^{[13]}$. During exposure time, mobile phones were kept in silent ringing, non-vibrating, auto redial activated mode. Exposure was done in a fixed time daily, 120 minutes per day, 6 days a week, for ten weeks. For the sham group (subgroup Ib), the cellular phones were placed beneath the cages with the phones turned off.

\section{E-Sample collection}

At the end of the experiment (24 hours after the last exposure to EMF), all rats were sacrificed. Fixation perfusion method was done using a mixture of $35 \mathrm{mg}$ heparin in $100 \mathrm{ml} \mathrm{4 \%}$ glutaraldehyde ${ }^{[14]}$. After perfusion fixation, animals were sacrificed by decapitation and the following organs were obtained:

I. Hippocampus: The brain was removed from the skull. Hippocampi were reached from the medial side after division of the brain at the mid sagittal plane and removal of the cerebellum ${ }^{[15]}$.

II. Testis: Each testis was dissected by abdominal incision and cleared from adhering connective tissue.

III. Epididymis: the right epididymis was collected for semen analysis.

Bodies of the dead animals were disposed-off using the incinerator.

\section{F-Preparation of tissue}

I-Hippocampi: were immediately fixed in $10 \%$ formalin saline for seven days followed by dehydration in ascending grades of ethyl alcohol, clearing, and then embedding in paraffin. Paraffin sections were cut at 4-6 $\mu \mathrm{m}$ and were stained by hematoxylin and eosin (HandE) stain and toluidine blue $\operatorname{stain}^{[16]}$.

II-Testis: were subjected to the following:

a-Light microscopic study

The right testis from each rat was fixed immediately in aqueous Bouin's solution and processed to obtain paraffin sections of $5 \mu \mathrm{m}$ thickness. They were stained with HandE and Mallory's trichrome stain ${ }^{[16]}$

\section{b-Immunohistochemical study}

The left testis was cut into two halves. One half was fixed in formalin saline and processed to obtain paraffin sections of $5 \mu \mathrm{m}$ thickness. Sections were cut on positively charged slides and were subjected to caspase- 3 immune 
reaction ${ }^{[16]}$. Caspase-3 (ready to use) was used for detection of apoptosis. Negative controls were processed according to the same protocol, except for the use of the primary antibody. Positive control was done on a section of tonsils. The kit was purchased from Lab vision, CA, USA.

\section{c-Transmission electron microscopic (TEM) study}

The other half of the left testis was cut into small pieces about $1 \mathrm{~mm} 3$ and were rapidly fixed in $2.5 \%$ glutaraldehyde. Specimens were processed and embedded in Epon resin. Semithin sections $(50 \mathrm{~nm})$ were stained with toluidine blue. Ultrathin sections were cut and mounted on copper grids $^{[16]}$. Specimens were examined and photographed using a JEM 1200 EXII, JEOL, Tokyo, Japan transmission electron microscope at the Regional Center for Mycology and Biotechnology, Al Azar University.

\section{G-Semen analysis study ${ }^{[17]}$}

The right epididymis was quickly removed from all rats. Each epididymis was macerated by scissors into four parts then they were left in in a hollow plate containing $1 \mathrm{ml}$ physiological saline. The tissue was left for 30-60seconds to let sperms leak from the tubules (the solution will tint whitish/grayish). The resulted fluid was handled as the semen. Sperm suspension was collected into an Eppendorf tube to perform the semen analysis using Eosin- Nigrosin staining technique.

Two drops of $1 \%$ aqueous Eosin $\mathrm{Y}$ were added to one drop of semen and were mixed with a wooden stirrer for 15 seconds. Then two drops of $10 \%$ aqueous Nigrosin were added and mixed well with a wooden stirrer. Thin smears were made immediately and were let air-dry. Nigrosine provides a dark background that make it easy to visualization of sperm. Live spermatozoa have white or faint pink heads, and dead spermatozoa have heads that are stained red or dark pink.

\section{H-Morphometric study}

It was performed using the image analyzer Leica Q win V. 3 program installed on a computer in the Histology and Cell Biology Department, Faculty of Medicine, Ain Shams University. The computer was connected to a Leica DM2500 microscope (Wetzlar, Germany). Specimens from all groups were subjected to morphometric study. Measurements were taken from five different slides obtained from each specimen. Five different non-overlapping fields were examined from each slide to measure the following:

1. Mean thickness of pyramidal cell layer of CA1 and CA3 areas of hippocampus and granule cell layer in dentate gyrus (HandE-stained sections X40)

2. Mean diameter of seminiferous tubules (HandE X20)

3. Mean thickness of germinal epithelium (HandE X20)

4. Mean area percentage of collagen fibers in Mallory's trichrome stained sections (X20)
5. Mean area percentage of positive reaction of caspase-3 sections (X20)

For mean diameter of seminiferous tubules, rounded transversely cut tubules were selected and two diameters of each tubule, one perpendicular to the other, were measured and the average was taken ${ }^{[18]}$.

\section{I-Statistical study}

Data were collected, revised then subjected to statistical analysis using one-way ANOVA performed by SPSS.21 program (IBM Inc. Chicago, Illinois, USA). Data were presented as mean \pm standard deviation (SD) The significance of the data was determined by $P$ value $(P>0.05$ was considered non-significant and $P<0.05$ significant).

\section{RESULTS}

\section{A-Histological results}

Examination of the hippocampus and testis from subgroups Ia and Ib showed similar results.

\section{I-Hippocampus}

Examination of HandE stained sections of control brain showed the hippocampal formation formed of the dentate gyrus and the hippocampal proprius (proper). The hippocampus proper was formed of four regions of cornu ammonis (CA) (CA1, CA2, CA3, and CA4). Area CA2 was dorsally situated while, $\mathrm{CA} 3$ formed the descending medial arch that terminated in the hilus of the dentate gyrus. CA4, lied within the hilus of the dentate gyrus and was often referred to as the end-plate. Each region of hippocampus proper appeared formed of three layers; superficial molecular, middle pyramidal and deep polymorphic layers. The dentate gyrus was a dark V-shaped structure, with its open portion surrounding CA4 area of the hippocampus. Dentate gyrus was formed of three layers. Molecular layer, granular cell layer and polymorphic layer which was seen on both sides of CA4 area. The supra-pyramidal blade and infra-pyramidal blade of the dentate gyrus were seen, and the meeting of both blades occurred at the crest of dentate gyrus (Figure 1).

Examination of CA2 area showed no significant changes between different groups. Both supra pyramidal and infrapyramidal blades of dentate gyrus had the same histological structure; hence, this whole study was performed on the supra pyramidal blade.

In the control group, pyramidal layer in CA1 and CA3, was formed of crowded, evenly arranged 3-4 rows of pyramidal cells with little neuropil in between. Most pyramidal cells were nearly of the same size. Each cell had basophilic cytoplasm and contained a single, central rounded large, vesicular nuclei with 2-3 prominent nucleoli. The CA3 area showed large pyramidal loosely packed neurons (Figures $2 \mathrm{a}$ and $2 \mathrm{~b}$ ). The dentate gyrus was formed of three layers, molecular, granular and polymorphic layer. The granular layer was formed of many granular cell neurons with little interstitial tissue in-between (Figure 2c). Glial 
cell interneurons were seen in all layers of hippocampus. They appeared as dark basophilic stained small rounded nuclei (Figure 2)

In single exposure group, examination of CA1 area showed some pyramidal cells with swollen karyolitic pale stained nuclei (Figure 3a). In CA3 area, cells with deep basophilic cytoplasm were seen, some cells were seen shrunken with deep basophilic cytoplasm and shrunken deeply stained nuclei. Perineural spaces were seen surrounding degenerated pyramidal cells (Figure 3b). In dentate gyrus, some granule cells appeared shrunken with deeply stained basophilic cytoplasm and shrunken pyknotic nuclei (Figure 3c).

In multiple exposure group, nerve cells with deep basophilic cytoplasm were frequently seen in CA1, CA3 and dentate gyrus. Perineural spaces were seen surrounding degenerated nerve cells. In CA1 area, an apparent decrease thickness of pyramidal layer was noticed compared to control group (Figure 4a). In CA3 area, pyramidal cells lost their even, regular arrangement. They were separated by wide neuropil. Swollen pyramidal cells with karyolitic pale stained nuclei were frequently seen (Figure $4 \mathrm{~b}$ ). The dentate gyrus showed an apparent decreased thickness of granule cell layer compared to control group. Shrunken granule cells with deeply stained basophilic cytoplasm and shrunken deeply stained pyknotic nuclei were seen. (Figure 4c).

Toluidine blue stained sections of hippocampus of control rats showed basophilic Nissl granules in the cytoplasm of pyramidal cells in CA1, CA3 (Figures 5a and 5b) and granule cells in dentate gyrus (Figure 5c). In single exposure group, most pyramidal cells in CA1 and CA3 were seen with basophilic Niss1 granules (Figures 6a and 6b) while in dentate gyrus, some granule cells were seen with few Nissl granules (Figure 6c). In multiple exposure group, some pyramidal cells in CA1 and CA3 areas of hippocampus were seen with few Nissl granules. Also, cell margins of damaged pyramidal neurons could not be determined (Figures $7 \mathrm{a}$ and $7 \mathrm{~b}$ ). In CA3 area, pyramidal cells were less densely packed with wide inter cellular space between pyramidal cells. Cells with deep basophilic cytoplasm could be also noticed (Figure 7b). In dentate gyrus, granule cells were less densely packed with wide intercellular space. Most granules cells were seen with few Nissl granules. Some cells were seen with deep basophilic cytoplasm. Also, cell margins of damaged neurons were not obvious (Figures 7c).

\section{II-Testis}

Examination of HandE stained sections from control testis showed closely packed seminiferous tubules separated by narrow interstitial spaces containing blood vessels and clusters of interstitial Leydig cells with vesicular nuclei. Each seminiferous tubule was surrounded by a well-defined basement membrane and flattened myoid cells with flattened nuclei. The tubules were lined with stratified germinal epithelium formed of spermatogonia, primary spermatocytes, early and late spermatids. Sertoli cells were seen between the spermatogenic cells, resting on regular basement membrane. They had large pale vesicular nuclei. Spermatozoa were also seen within the lumen of seminiferous tubules (Figure 8a). In single exposure group, vacuolations were sometimes seen between spermatogenic cells (Figure 8b). While, in multiple exposure group, thickening and corrugation of basal lamina were noticed in some seminiferous tubules. An apparent reduction in the thickness of germinal epithelium, distorted spermatogenic cells with fragmented nuclei and wide intercellular spaces between spermatogenic cells were seen. Absence of sperms inside the lumen of seminiferous tubules were sometimes noticed (Figure 8c).

In Mallory`s trichrome stained sections of control and single exposure groups, few collagen fibers were seen around seminiferous tubules (Figures $9 \mathrm{a}$ and $9 \mathrm{~b}$ respectively). While in multiple exposure group, an apparent increase amount of collagen fibers was noticed around and in-between seminiferous tubules (Figure 9c).

In Caspase-3 immunohistochemical reaction of control group, negative reaction was seen in spermatogenic cells and interstitial Leydig cells (Figures 10a). In single exposure, mild caspase- 3 positive reaction was seen in cytoplasm of Leydig cells (Figure 10b). While in multiple exposure group, positive reaction was noticed in the cytoplasm of some Leydig cells (Figure 10c).

In toluidine blue stained sections of control group, the epithelium of seminiferous tubules was seen resting on regular basement membrane. Spermatogonia were seen with rounded to oval nuclei, columnar Sertoli cells occupied spaces between adjacent spermatogenic cells. They had large vesicular nuclei. Primary spermatocytes were the largest germ cells found within seminiferous tubules, they were present in the middle layers of the germinal epithelium. And were readily recognized by their spherical outline and large nucleus with either thin threads or coarse clumps of chromatin. Early spermatids were small rounded cells with small rounded nuclei. And late spermatids with diamond shaped irregular nuclei were seen. Darkly stained acrosomal cap was also seen covering the anterior part of spermatids (Figure 11a). In single exposure group, vacuolations were sometimes noticed near the basement membrane (Figure 11b). While in multiple exposure group, extensive vacuolations were seen between spermatogenic cells in most seminiferous tubules. Disorganized arrangement of spermatogenic cells which were seen separated with wide intercellular spaces could be seen in some tubules. Also, ill-defined cell boundaries were sometimes noticed in spermatogenic cells (Figure 11c).

Examination of Nigrosin-Eosin sperm smear of the control group showed normal sperms with hook shaped heads and tail (Figure 12a). In single exposure group, 
abnormal sperms with detached head, coiled tails and sperms with their tails bend towards the head could be seen (Figure 12b). While in multiple exposure group, the amount of abnormal sperms was apparently increased. Headless sperms which lack hook-shaped heads and sperms with bend head were noticed. Sperms with coiled tail or constriction in the tail were also seen. Dead sperms could sometimes be detected. They appeared with dark pink stain (Figure 12c).

Transmission electron microscopic examination of testis of control rats showed columnar Sertoli cells with their large pale euchromatic indented nuclei, complex lateral and apical infoldings that housed the developing gametes and tight junctions were seen in the lateral processes of Sertoli cells. The cytoplasm contained smooth endoplasmic reticulum, mitochondria, and lipid droplets. Sertoli cell appeared resting on a regular basement membrane surrounded by myoid cells. primary spermatocytes were seen with large nuclei (Figure 13a). Early spermatids were detected by many peripherally arranged mitochondria with a clear matrix. Acrosomal vesicles condense and wrap around their nuclei. Large lysosome (acrosin) was seen covering the anterior portion of sperms head. The anterior two-thirds of the nucleus was covered by the acrosome (Figure 13b). Maturing spermatids were seen with condensation of the nuclear chromatin, excess cytoplasm was seen arising from the posterior part of the spermatids. Microtubules arise from the posterior margin of acrosmal cap forming the manchette (Figure 13c). Interstitial Leydig cells with their peripheral microvilli were seen containing large euchromatic nuclei and thin rim of peripheral dense chromatin. The cytoplasm contained smooth endoplasmic reticulum, mitochondria, well developed Golgi and numerous electron-dense lipid droplets (Figure 13d).

In single exposure group, spermatogonia and Sertoli cells were seen resting on regular basement membrane. Vacuolations were sometimes seen between the cells (Figure 14a). Intercellular bridges were seen between primary spermatocytes (Figure 14b). Some Leydig cells were seen with dilated smooth endoplasmic reticulum (Figure 14c).

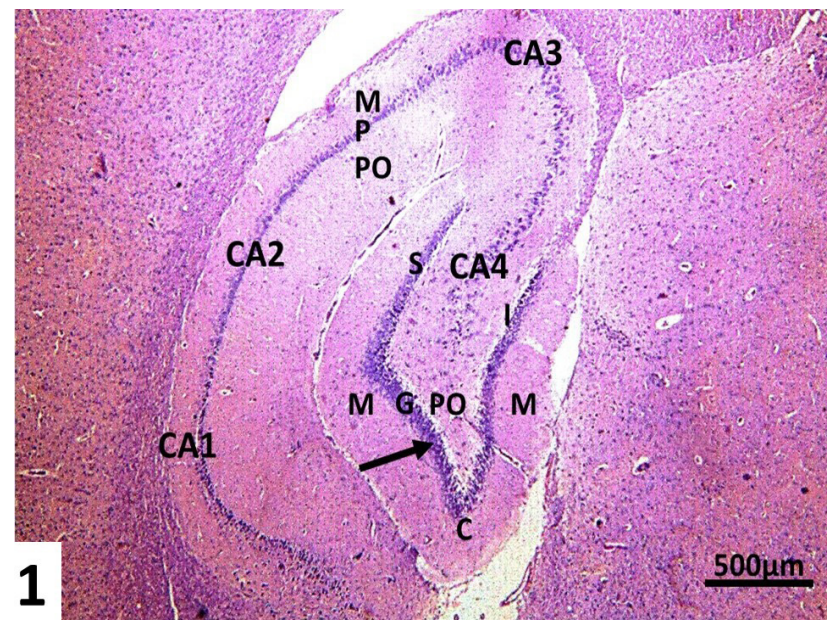

In multiple exposure group, spermatogonia and Sertoli cells were seen resting on the basement membrane. Inter cellular vacuoles were frequently seen between spermatogenic cells. (Figure 15a). Primary spermatocytes were seen distorted with irregular shrunken indented nuclei and elongated mitochondria (Figure 15b). Some early spermatids were seen with disturbed mitochondrial arrangement (Figure 15c). Most Leydig cells were seen with elongated mitochondria, dilated smooth endoplasmic reticulum and clumped nuclear chromatin (Figure 15d).

\section{B-Histomorphometric results}

\section{I-Hippocampus (Table 1, Histogram 1)}

In single exposure group, non-significant decrease was noticed in the mean thickness of pyramidal layer in CA1 and CA3 areas and granular layer of dentate gyrus compared to control group, while a significant increase was noticed compared to multiple exposure group.

In multiple exposure group, a significant decrease in the mean thickness of pyramidal layer in CA1 and granule cell layer of dentate gurus was noticed compared to control and single exposure groups.

\section{II-Testis (Table 2, Histograms 2 and 3)}

In single exposure group, a significant decrease in the mean diameter of seminiferous tubules and the mean thickness of germinal epithelium was noticed compared to control group. While a significant increase was noticed compared to multiple exposure group.

A non-significant increase was noticed in the mean area percentage of collagen fibers and Caspase- 3 reaction was noticed compared to control group while, a significant decrease was noticed compared to multiple exposure group.

In multiple exposure group, a significant decrease in the mean diameter of seminiferous tubules, mean thickness of germinal epithelium and significant increase in the mean area percentage of collagen fiber and Caspase-3 reaction was noticed compared to control group and single exposure group.

Fig. 1: a sagittal section of a rat control brain showing an over view of hippocampal formation: the hippocampal proprius (proper) and the dentate gyrus $(\uparrow)$. The hippocampus proper is formed of four regions of cornu ammonis (CA1, CA2, CA3, and CA4). Each is formed of three layers; superficial molecular (M), middle pyramidal (P) and deep polymorphs layers (PO). The dentate gyrus is seen as a dark V-shaped structure, with its open portion surrounding CA4 area of the hippocampus. The dentate gyrus is formed of three layers; molecular layer (M), granule cell layer $(\mathrm{G})$, and polymorphic layer (PO) which is seen on both sides of CA4 area. The supra-pyramidal blade (S) and infra-pyramidal (I) blade of the dentate gyrus are seen. The meeting of both blades occurs at the crest (C) of dentate gyrus. HandE X 40. Scale bar: $500 \mu \mathrm{m}$ 


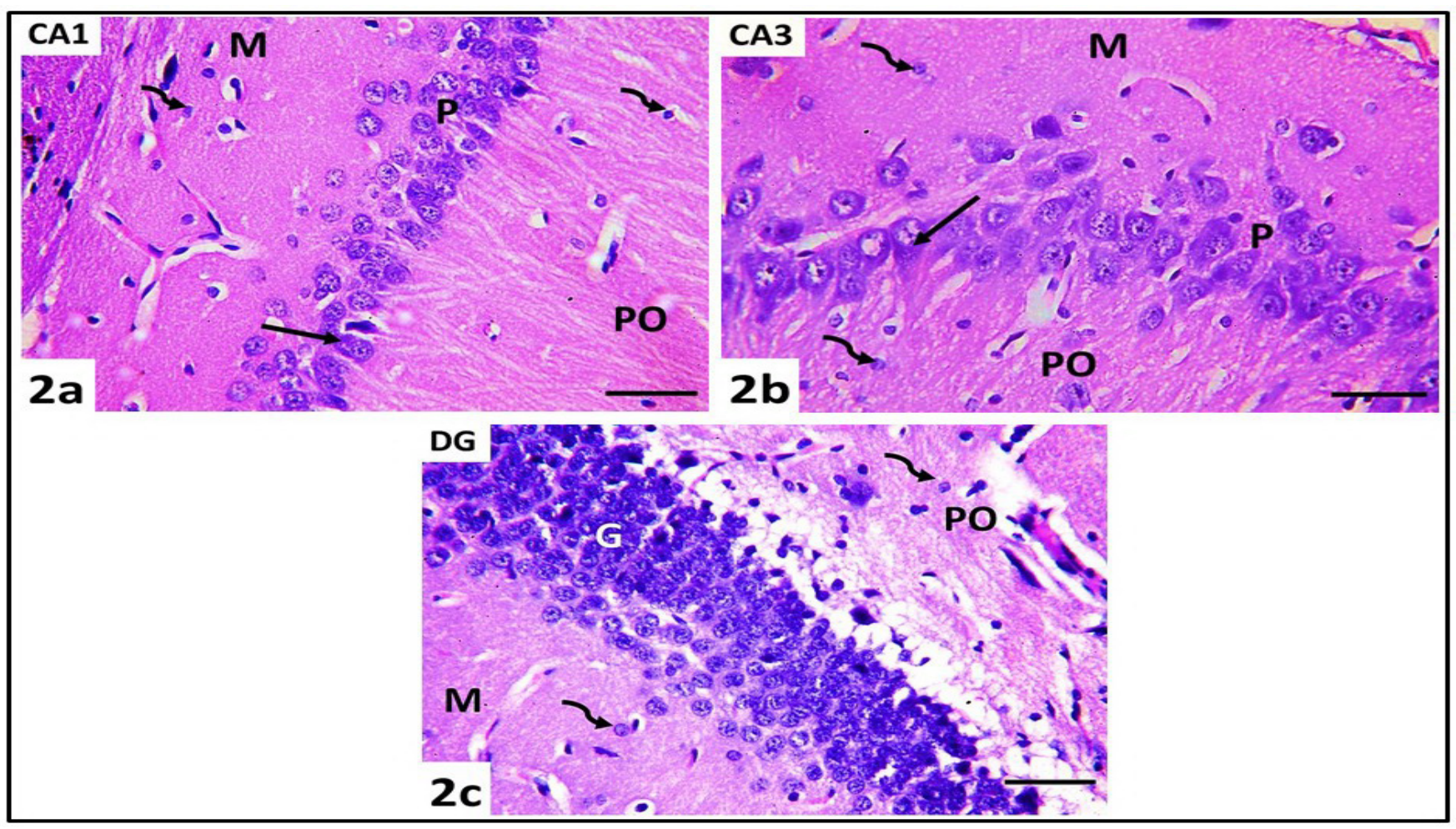

Fig. 2: photomicrographs of hippocampus from control group. (2a) CA1 and (2b) CA3 areas: Each is formed of superficial molecular layer (M), middle pyramidal layer (P) and deep polymorphic layer (PO). Pyramidal layer is formed of crowded, evenly arranged 3-4 rows of pyramidal neurons with little neuropil in between. Most pyramidal cells are nearly of the same size. Each cell has basophilic cytoplasm ( $\uparrow$ ) and contains a single, rounded central large, vesicular nucleus with 2-3 prominent nucleoli. The CA3 region shows large pyramidal loosely packed neurons. (2c) dentate gyrus (DG) is formed of three layers; molecular layer $(\mathrm{M})$, middle granular cell layer $(\mathrm{G})$ and polymorphic layer $(\mathrm{PO})$. The granular layer is formed of many granular cell neurons with little interstitial tissue in-between. Glial cell interneurons are seen in all layers of hippocampus. They appear as dark basophilic stained small rounded nuclei (curved arrow). HandE X 400. Scale bar: $50 \mu \mathrm{m}$

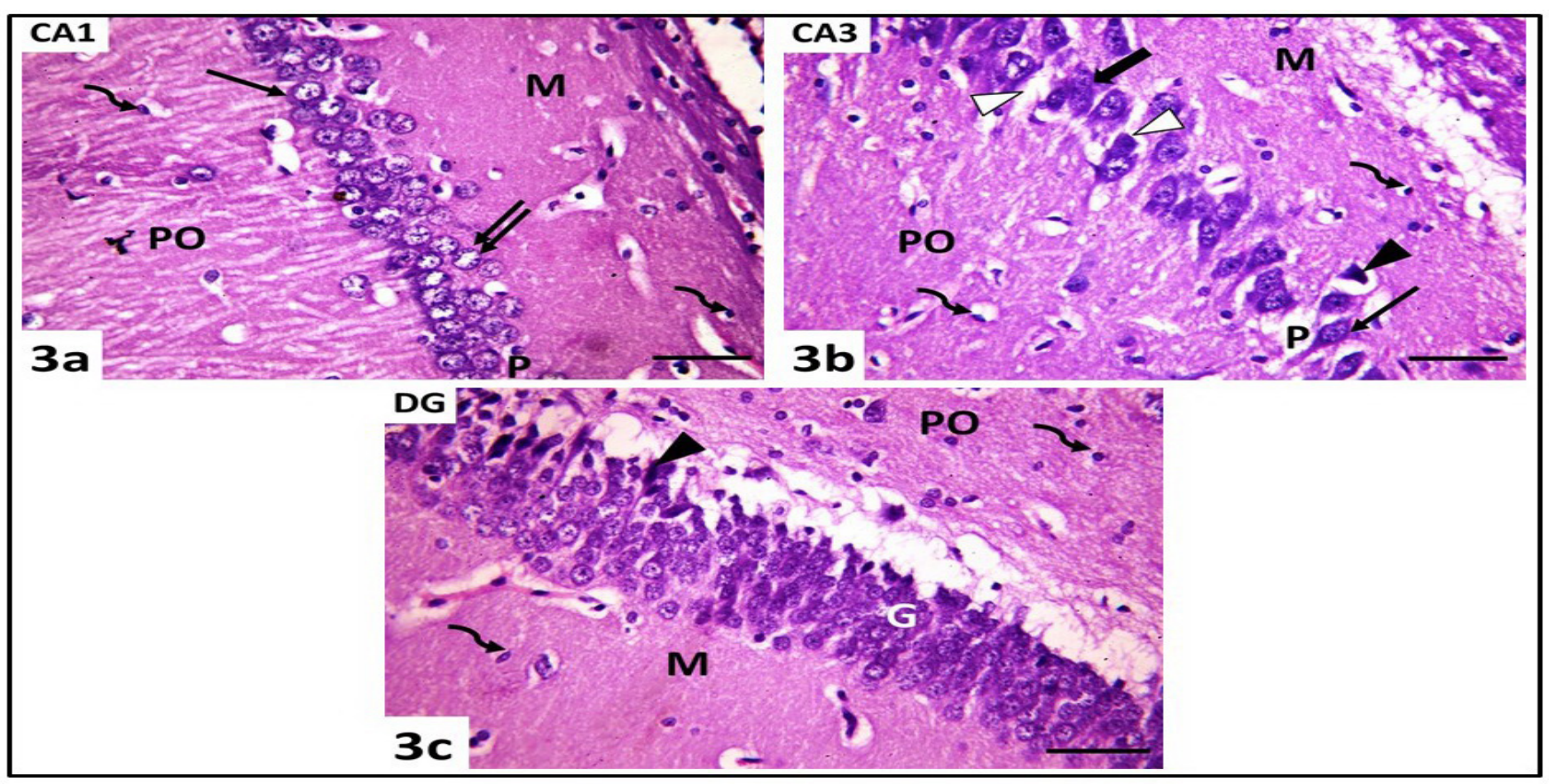

Fig. 3: photomicrographs of hippocampus from single exposure group. (3a) CA1 and (3b) CA3 areas: Each is formed of molecular layer (M), pyramidal layer (P) and polymorphic layer (PO). Normal pyramidal cells with basophilic cytoplasm and large central rounded vesicular nuclei ( $\uparrow$ ) are seen. (3a) CA1 area: contains pyramidal cells with swollen karyolitic pale stained nuclei ( $\uparrow$ ). (3b) CA3 area: showed shrunken pyramidal cells with deeply stained basophilic cytoplasm and shrunken deeply stained pyknotic nuclei $(\boldsymbol{\Delta})$, perineural space surrounding degenerated pyramidal cells $(\Delta)$ and degenerated pyramidal cells (thick arrow). (3c) dentate gyrus (DG) is formed of molecular layer (M), granular cell layer (G) and polymorphic layer (PO). Shrunken granule cells with deeply stained basophilic cytoplasm and shrunken deeply stained pyknotic nuclei $(\boldsymbol{\Delta})$ are seen. Glial cell interneurons are seen in all layers of hippocampus (curved arrow). 


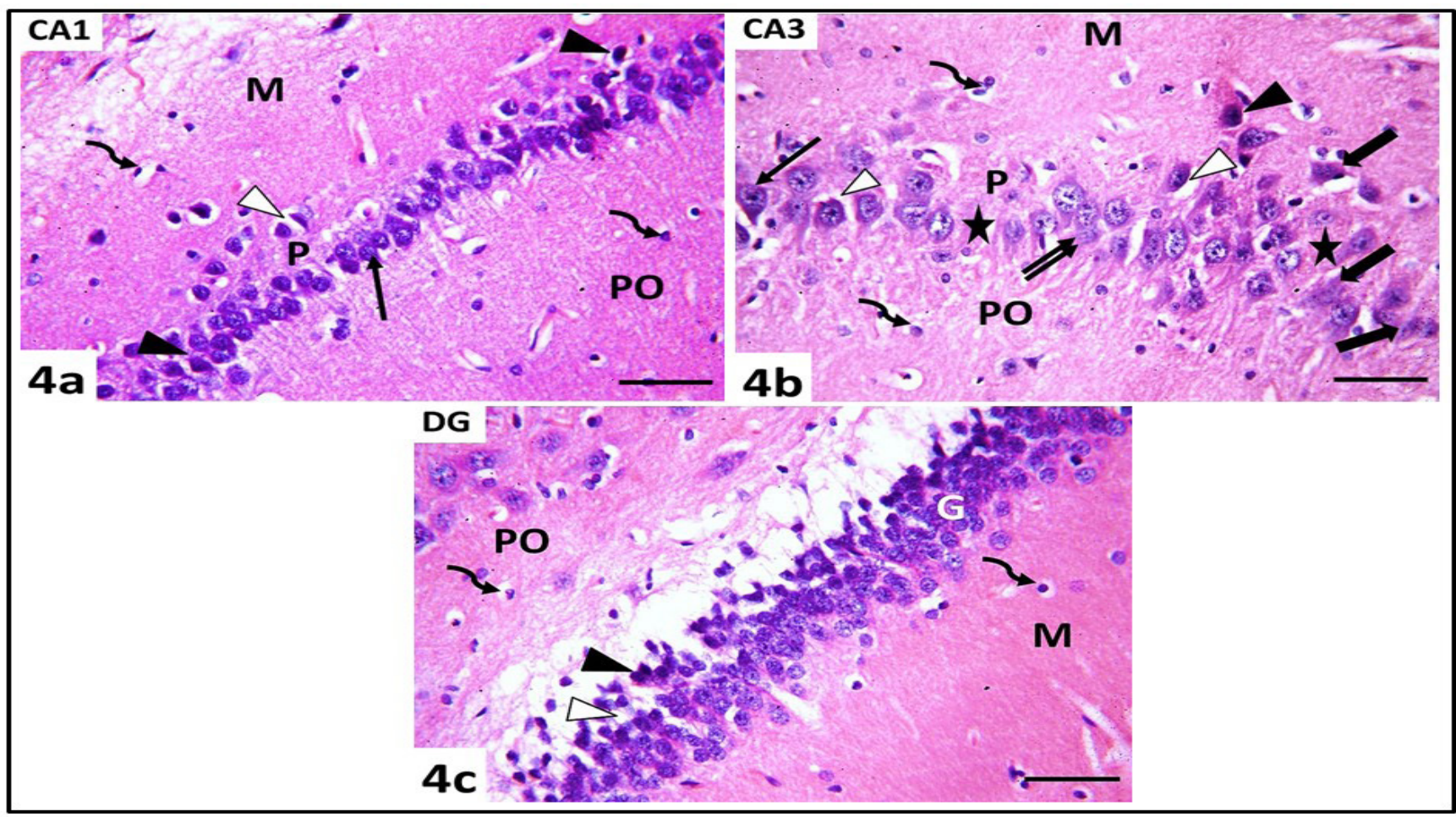

Fig. 4: photomicrographs of hippocampus from multiple exposure group. (4a) CA1 and (4b) CA3 areas: Each is formed of molecular layer (M), pyramidal layer (P) and polymorphic layer (PO). Normal pyramidal cells with basophilic cytoplasm and large central rounded vesicular nuclei $(\uparrow)$, shrunken deeply stained pyknotic nuclei $(\boldsymbol{\Delta})$ and perineural space surrounding degenerated pyramidal cells $(\Delta)$ can be seen in CA1 and CA3 areas. (4a) CA1 area showing an apparent decrease thickness of pyramidal cell layer compared to control group. (4b) CA3 area: pyramidal cells lose their even regular arrangement and are separated by wide interstitium (*). Pyramidal cells with karyolitic pale stained nuclei ( $\uparrow$ ) and degenerated pyramidal cells (thick arrow) are seen. (4c) dentate gyrus (DG) is formed of molecular layer (M), granular cell layer (G) and polymorphic layer (PO). An apparent decrease thickness of granular cell layer is noticed compared to control group. Shrunken granule cells with deeply stained basophilic cytoplasm and shrunken deeply stained pyknotic nuclei ( $\mathbf{\Delta}$ ) and perineural space surrounding degenerated nerve cells $(\Delta)$ can be seen. Glial cell interneurons are seen in all layers of hippocampus (curved arrow). HandE X 400 . Scale bar: $50 \mu \mathrm{m}$

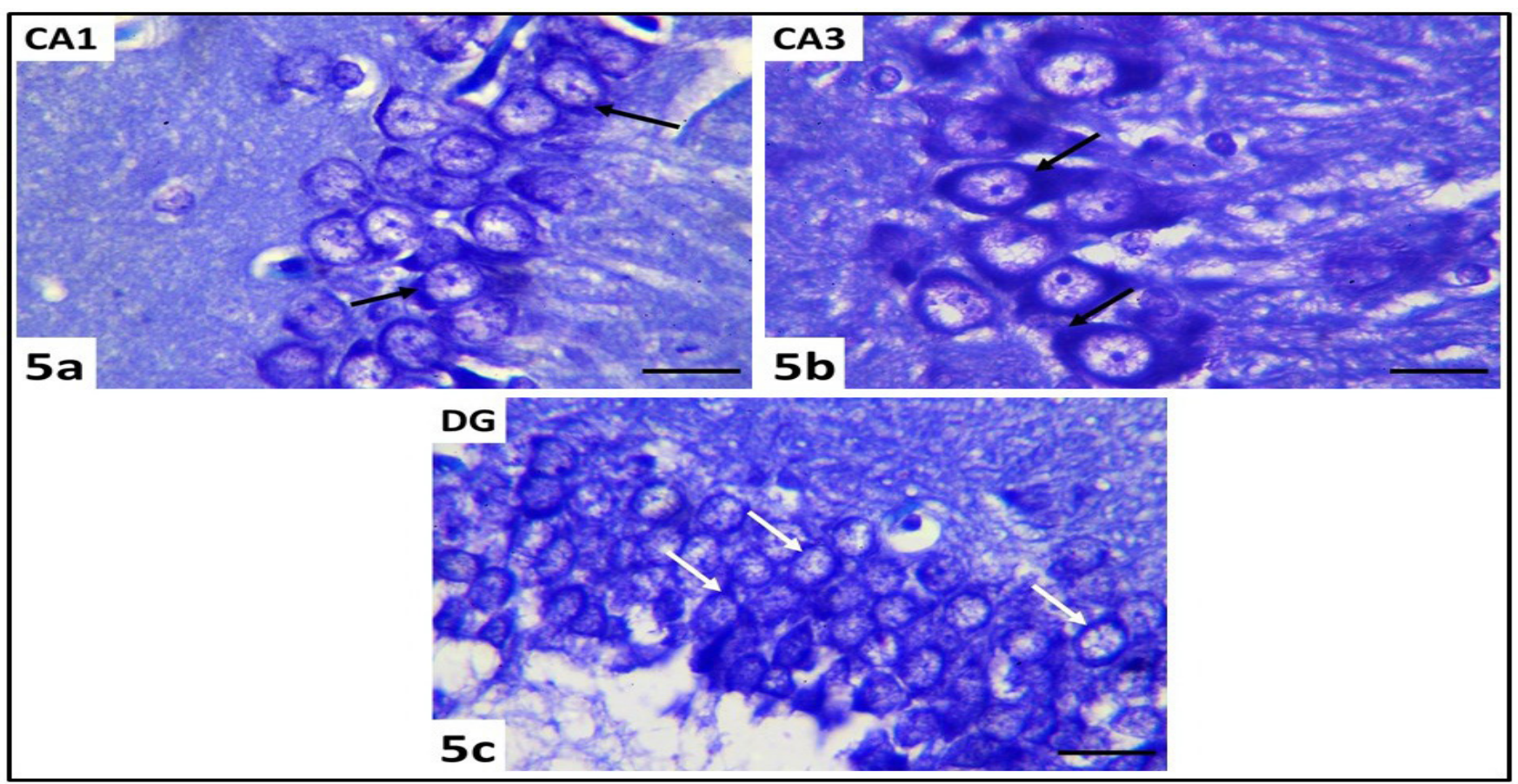

Fig. 5: photomicrographs of hippocampus from control group. (5a) CA1 area, (5b) CA3 area and (5c) dentate gyrus (DG). Nissl granules ( $\uparrow$ ) are seen in pyramidal cells and granule cells. Toluidine blue X 1000. Scale bar: $20 \mu \mathrm{m}$ 


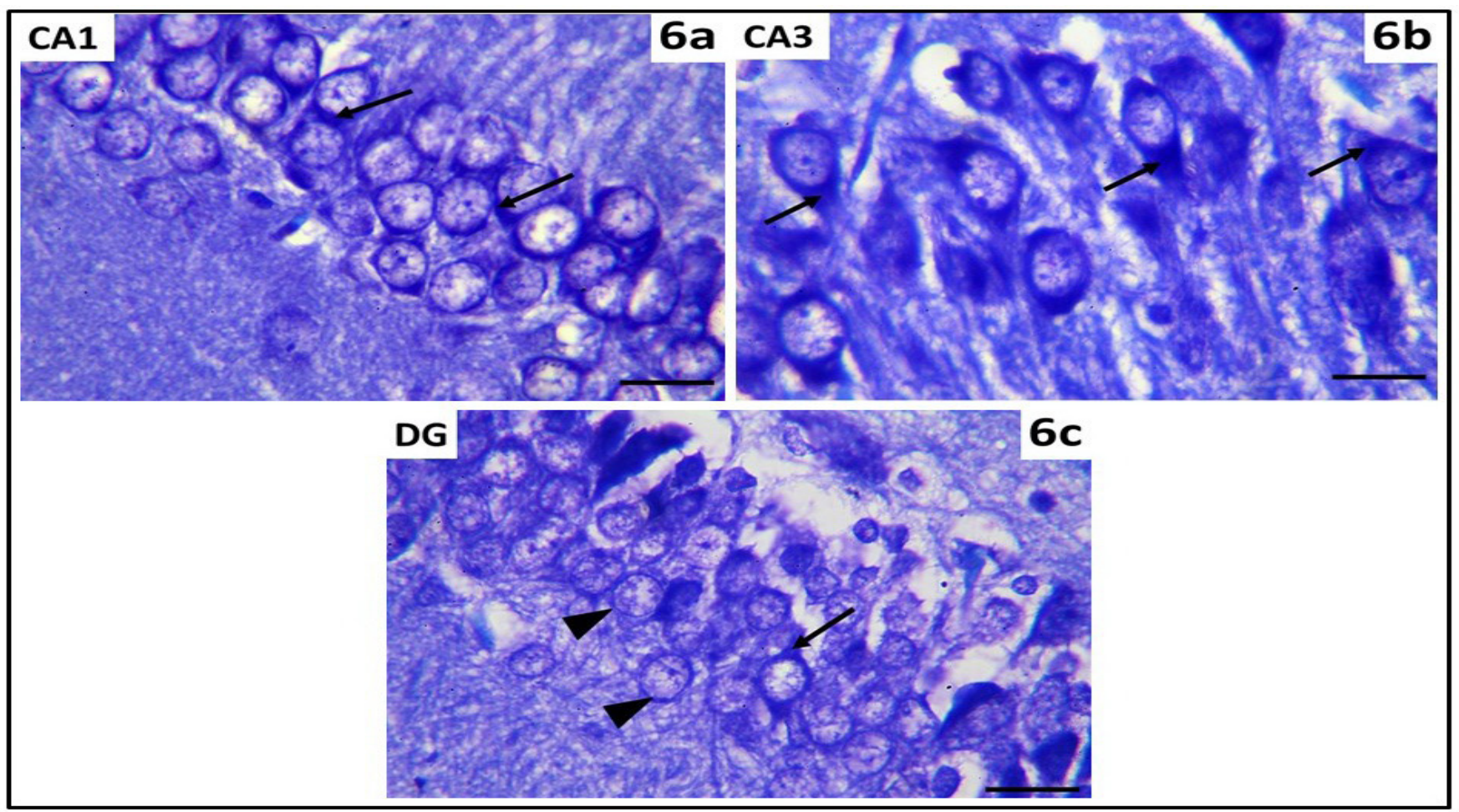

Fig. 6: photomicrographs of hippocampus from single exposure group. (6a) CA1 area, (6b) CA3 area and (6c) dentate gyrus (DG). Nissl granules ( $\uparrow$ ) are seen in pyramidal cells and granule cells of hippocampus. In (6c) some granule cells of dentate gyrus are seen with few Nissl granules ( $\mathbf{\Lambda}$ ). Toluidine blue X 1000. Scale bar: $20 \mu \mathrm{m}$

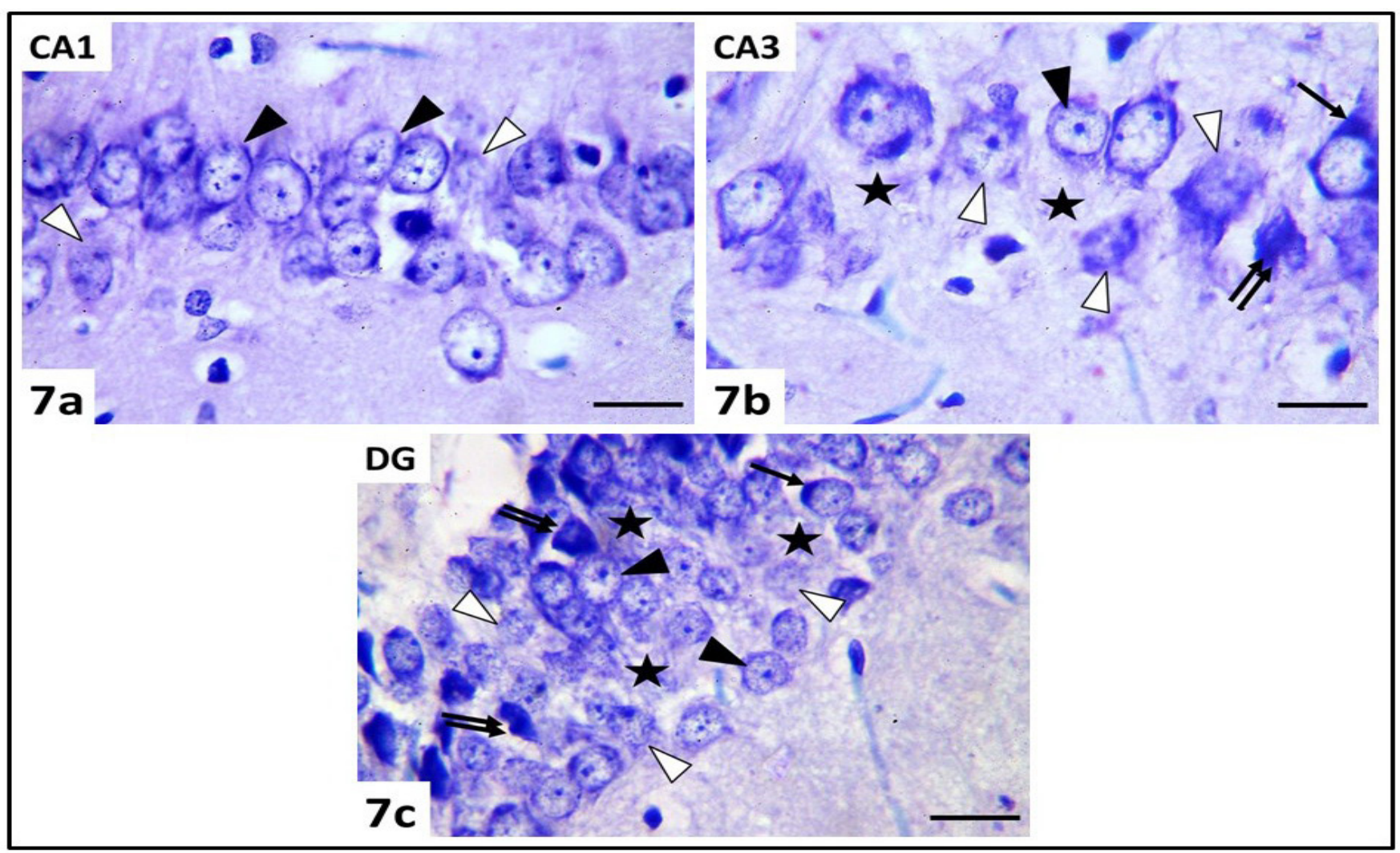

Fig. 7: photomicrographs of hippocampus from multiple exposure group. (7a) CA1 area: some pyramidal cells are seen with few Nissl granules $(\boldsymbol{\Lambda})$. Cell margins of damaged pyramidal neurons cannot be determined $(\Delta)$. (7b) CA3 area: pyramidal cells are less densely packed with wide inter cellular space between pyramidal cells $(*)$. Nissl granules $(\uparrow)$ are seen in some pyramidal cells. Other pyramidal cells are seen with few Nissl granules $(\boldsymbol{\Lambda})$. Cells with deep basophilic cytoplasm $(\uparrow \uparrow)$ and cell margins of damaged neurons cannot be determined $(\Delta)$. (7c) dentate gyrus (DG): Granule cells were less densely packed with wide inter cellular space between cells $\left(^{*}\right)$. Some granule cells are seen with few Nissl granules $(\mathbf{\Lambda})$. Cell margins of damaged granule cells cannot be determined $(\Delta)$ and cells with deep basophilic cytoplasm $(\uparrow \uparrow)$ can be observed. Toluidine blue X 1000. Scale bar: $20 \mu \mathrm{m}$ 


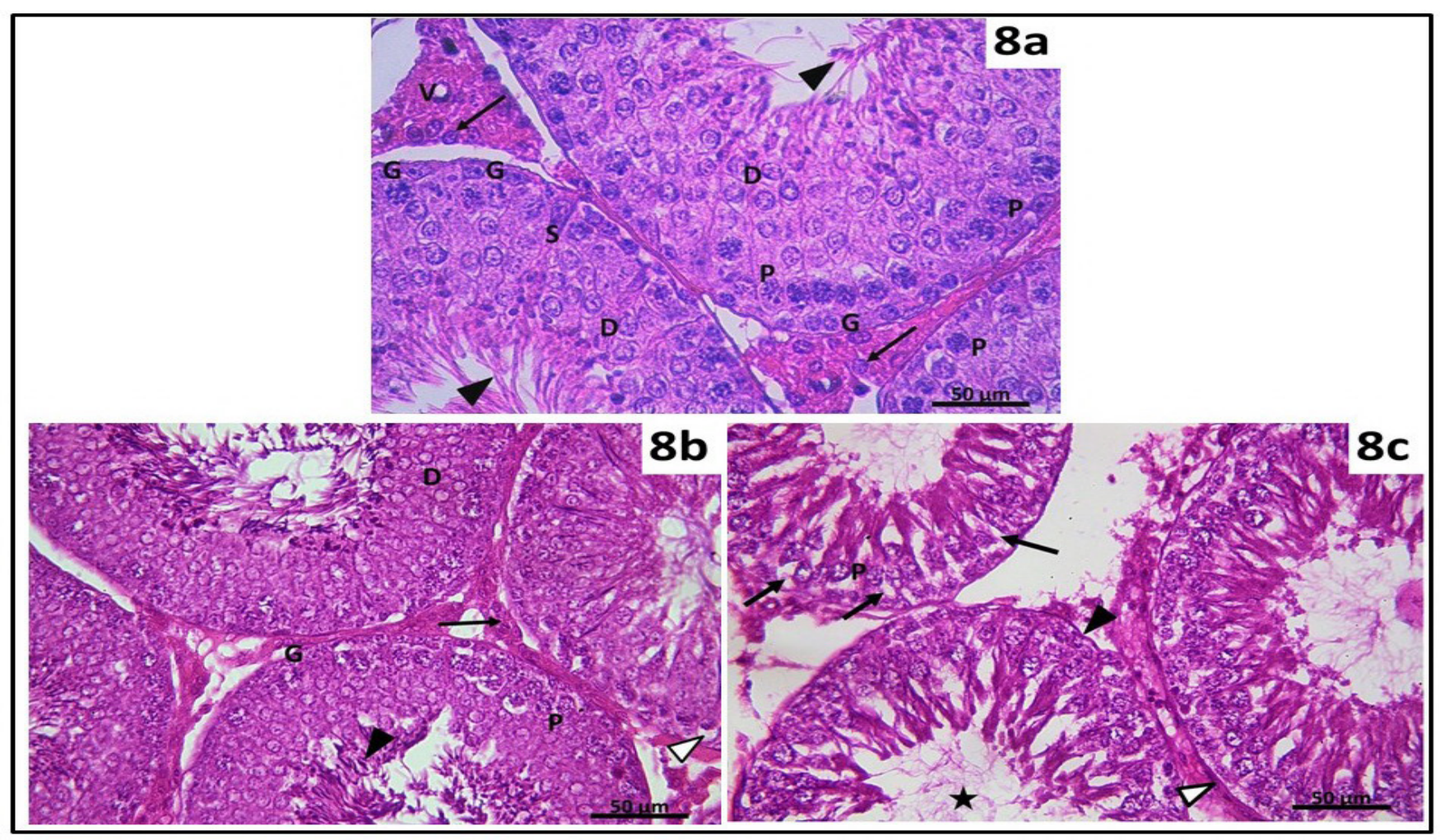

Fig. 8: photomicrographs of testis from (8a) control group: showing closely packed seminiferous tubules separated by narrow interstitial space. Spermatogonia $(\mathrm{G})$ and Sertoli cells (S) are resting on a regular basement membrane. Primary spermatocytes (P), early spermatids (D) and spermatozoa within the lumen ( $\boldsymbol{\Delta}$ ) can be seen. Clusters of interstitial Leydig cells ( $\uparrow$ ) with their vesicular nuclei and blood vessels $(\mathrm{V})$ are observed between the tubules. (8b) single exposure group: Leydig cells $(\uparrow)$ between seminiferous tubules, spermatogonia $(\mathrm{G})$, primary spermatocytes $(\mathrm{P})$, early spermatids (D) and late spermatids $(\boldsymbol{\Delta})$ are seen. Vacuolations $(\Delta)$ can be detected between basement membrane and some spermatogonia. (8c) multiple exposure group: Thickening $(\Delta)$ and corrugation $(\boldsymbol{\Delta})$ of basal lamina and apparent reduction in the thickness of germinal epithelium are seen. Distorted spermatogenic cells with fragmented nuclei, wide intercellular spaces $(\uparrow)$ between spermatogenic cells and absence of sperms inside the lumen of seminiferous tubules $(*)$ can also be seen. HandE X 400 . Scale bar: $50 \mu \mathrm{m}$

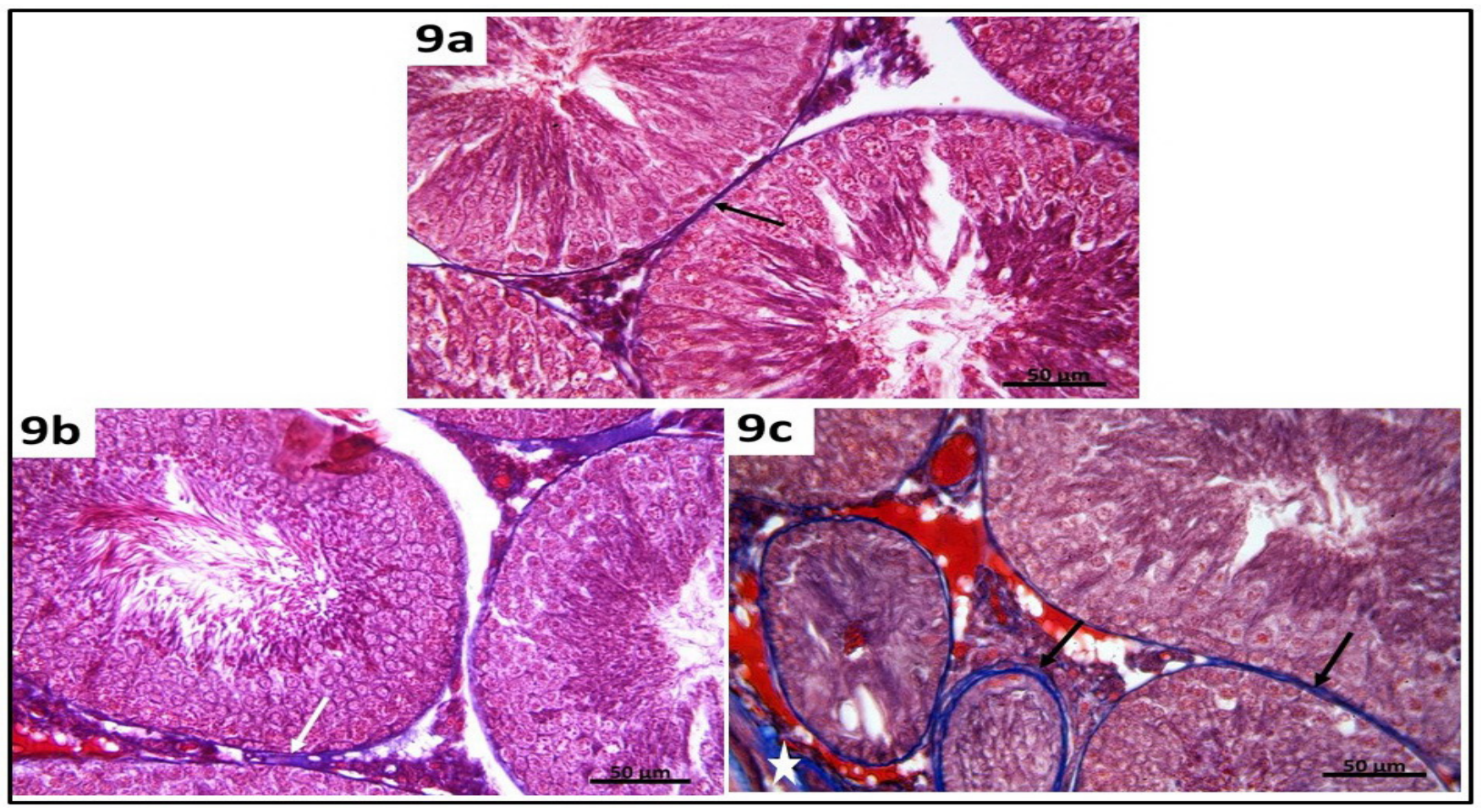

Fig. 9: photomicrographs of testis from (9a) control group: few collagen fibers $(\uparrow)$ are seen surrounding seminiferous tubules. (9b) single exposure group: few collagen fibers $(\uparrow)$ around seminiferous tubules $(9 \mathrm{c})$ multiple exposure group: an apparent increase amount of collagen fibers around $(\uparrow)$ and in-between $(*)$ seminiferous tubule. Mallory`s trichrome stain X400. Scale bar: $50 \mu \mathrm{m}$ 


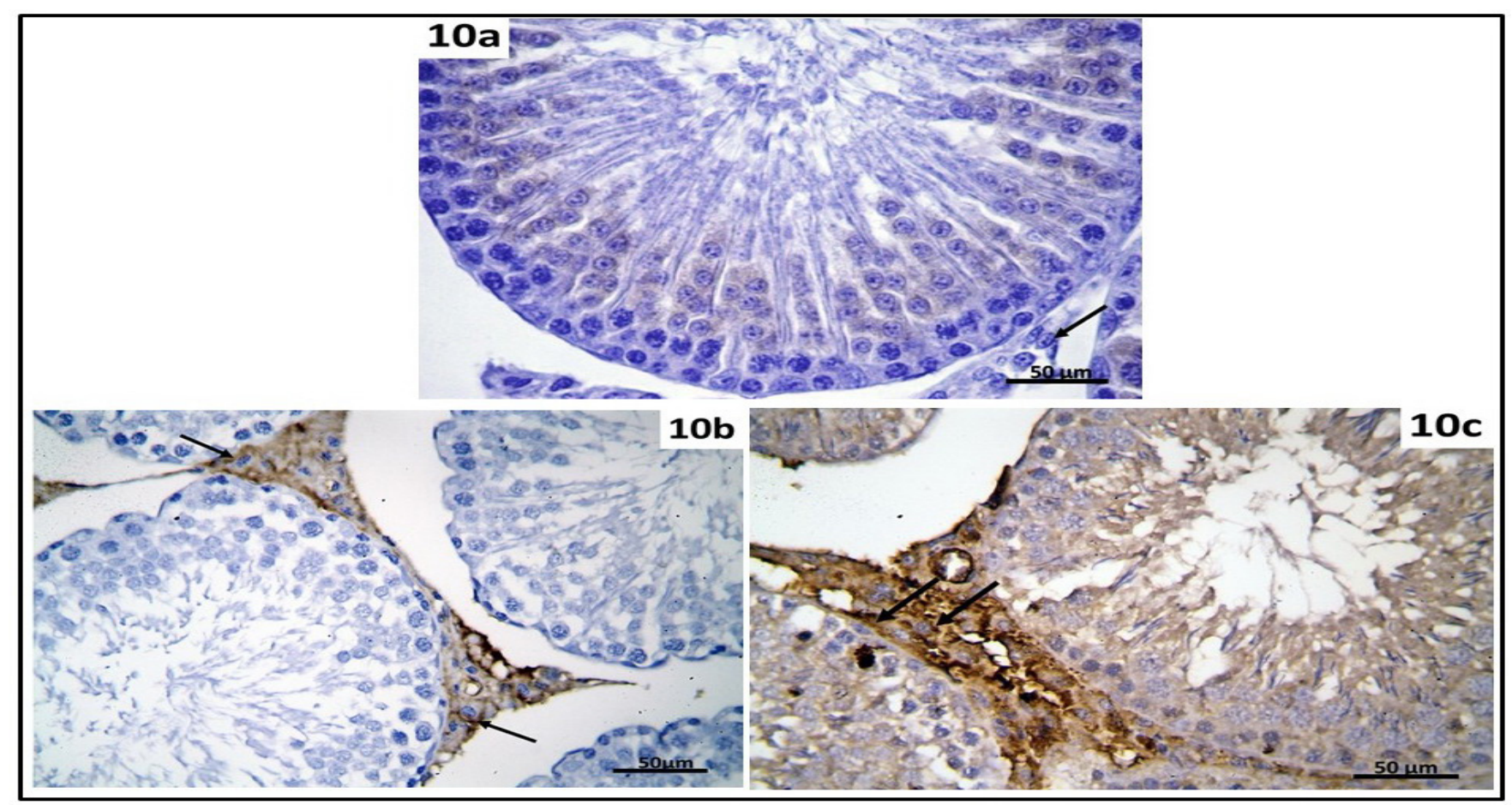

Fig. 10: photomicrographs of testis from (10a) control group: negative Caspase-3 reaction in cytoplasm of spermatogenic cells and interstitial cells of Leydig $(\uparrow)$. (10b) single exposure group: mild positive reaction is seen in cytoplasm of Leydig cells $(\uparrow)$. (10c) multiple exposure group: showing positive Caspase-3 reaction in the cytoplasm of Leydig cells $(\uparrow)$. Caspase-3 immunohistochemical reaction X400. Scale bar X 50 $\mu \mathrm{m}$

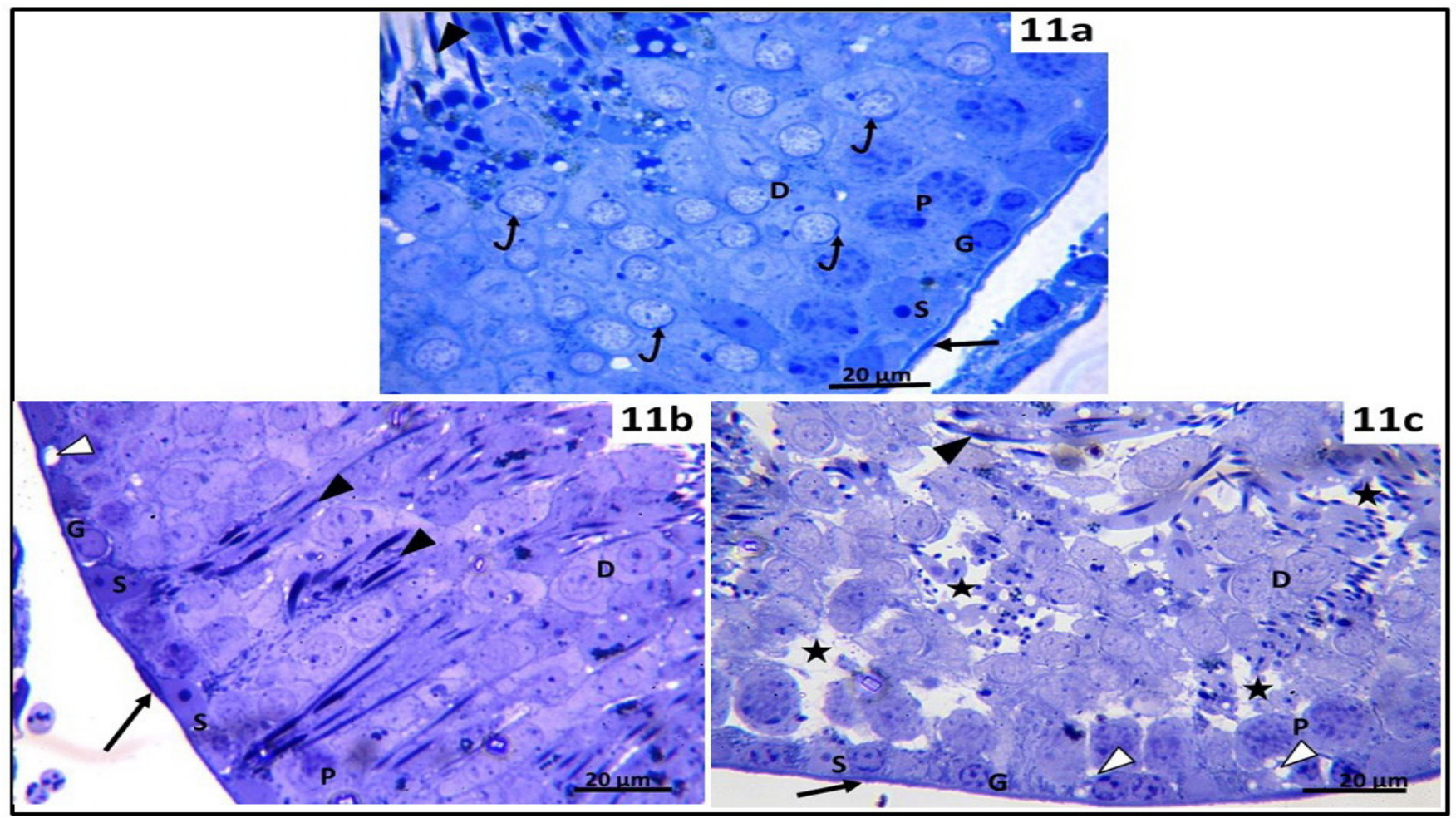

Fig. 11: photomicrographs of testis from (11a) control group: the epithelium of seminiferous tubules is seen resting on a regular basement membrane ( $\uparrow$ ) Spermatogonia (G) are seen with ovoid nuclei, and Sertoli cell (S) with large vesicular pale nucleus. Primary spermatocytes (P) are the largest germ cells within seminiferous tubules. They have large nuclei containing strands of condensed chromosomes. Early spermatids (D) are small rounded cells with small rounded nuclei and late spermatids $(\boldsymbol{\Lambda})$ are seen with diamond shaped irregular nuclei. Darkly stained acrosomal cap (curved arrow) is also noticed covering the anterior part of spermatids. (11b) single exposure group: vacuolations near the basement membrane $(\Delta)$ can be seen. Spermatogenic cells are seen resting on the basement membrane $(\uparrow)$. Spermatogonia $(G)$, Sertoli cells (S), primary spermatocytes $(P)$, early spermatids (D) and late spermatids $(\boldsymbol{\Delta})$ are also seen. (11c) multiple exposure group: vacuolations near the basement membrane $(\Delta)$ can be seen. Disorganized arrangement of spermatogenic cells which are seen separated by wide inter cellular spaces (*). Notice ill-defined cell boundaries of most spermatogenic cells. Basement membrane ( $\uparrow)$, spermatogonia $(\mathrm{G})$, Sertoli cells (S), primary spermatocytes (P), early spermatids (D) and late spermatids ( $\mathbf{\Delta}$ ) are also seen. Toluidine blue stain X 1000 . Scale bar:20 $\mu \mathrm{m}$ 


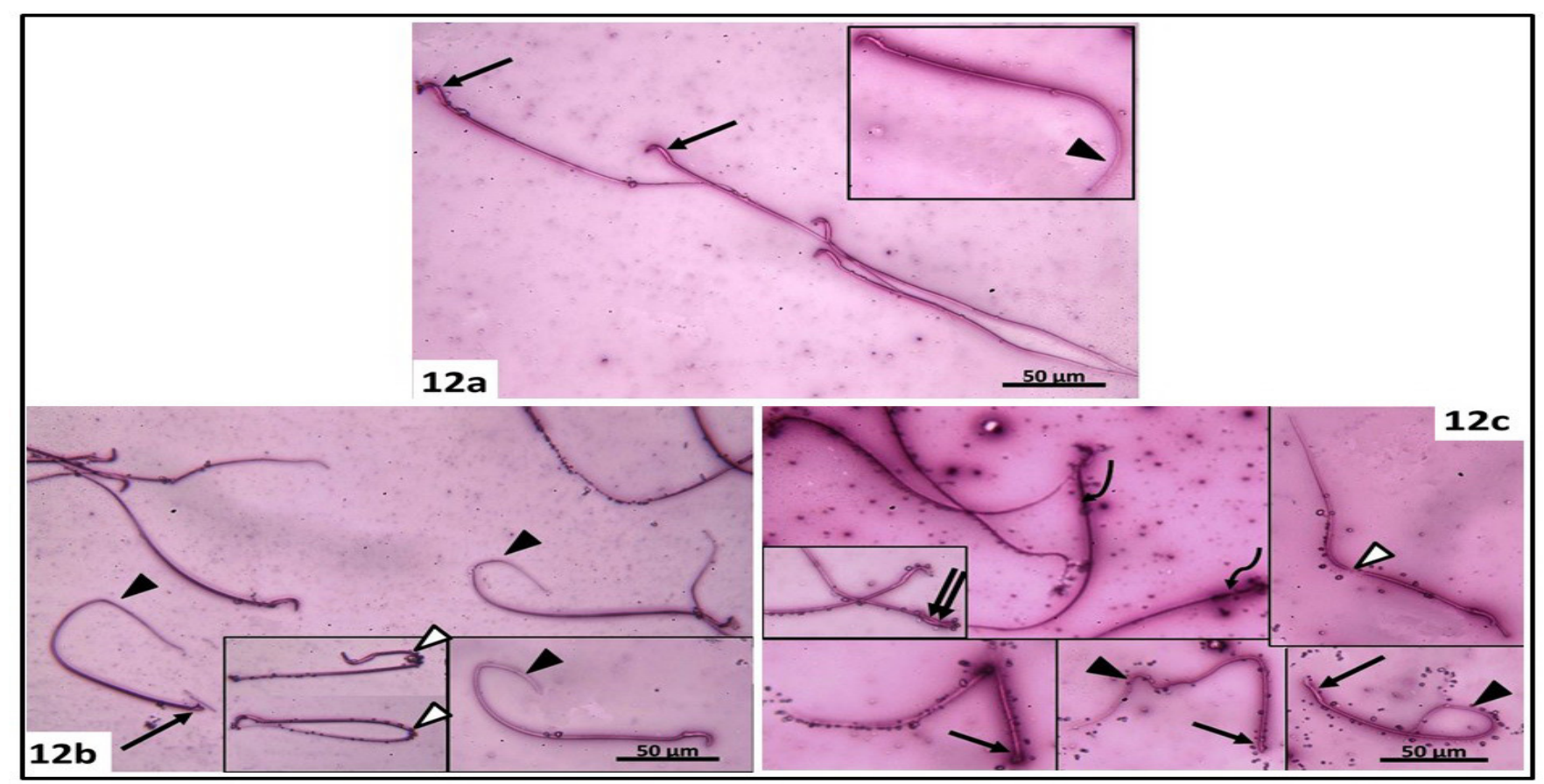

Fig. 12: photomicrographs of sperm smears from (12a) control group: normal sperms are seen with hook shaped heads ( $\uparrow)$ and tail $(\boldsymbol{\Delta})$. (12b) single exposure group: abnormal sperms with detached head $(\uparrow)$, coiled tail $(\boldsymbol{\Delta})$ and sperms with their tails bend towards the head $(\Delta)$ can be seen. (12c) multiple exposure group: sperms which lack hook-shaped heads (headless) $(\uparrow)$, bend head $(\uparrow \uparrow)$, coiled tail $(\boldsymbol{\Delta})$, constriction in the tail $(\Delta)$ and dead spermatozoa (curved arrow) with dark pink stain can be seen. Nigrosin Eosin sperm smear X400. Scale bar: $50 \mu \mathrm{m}$

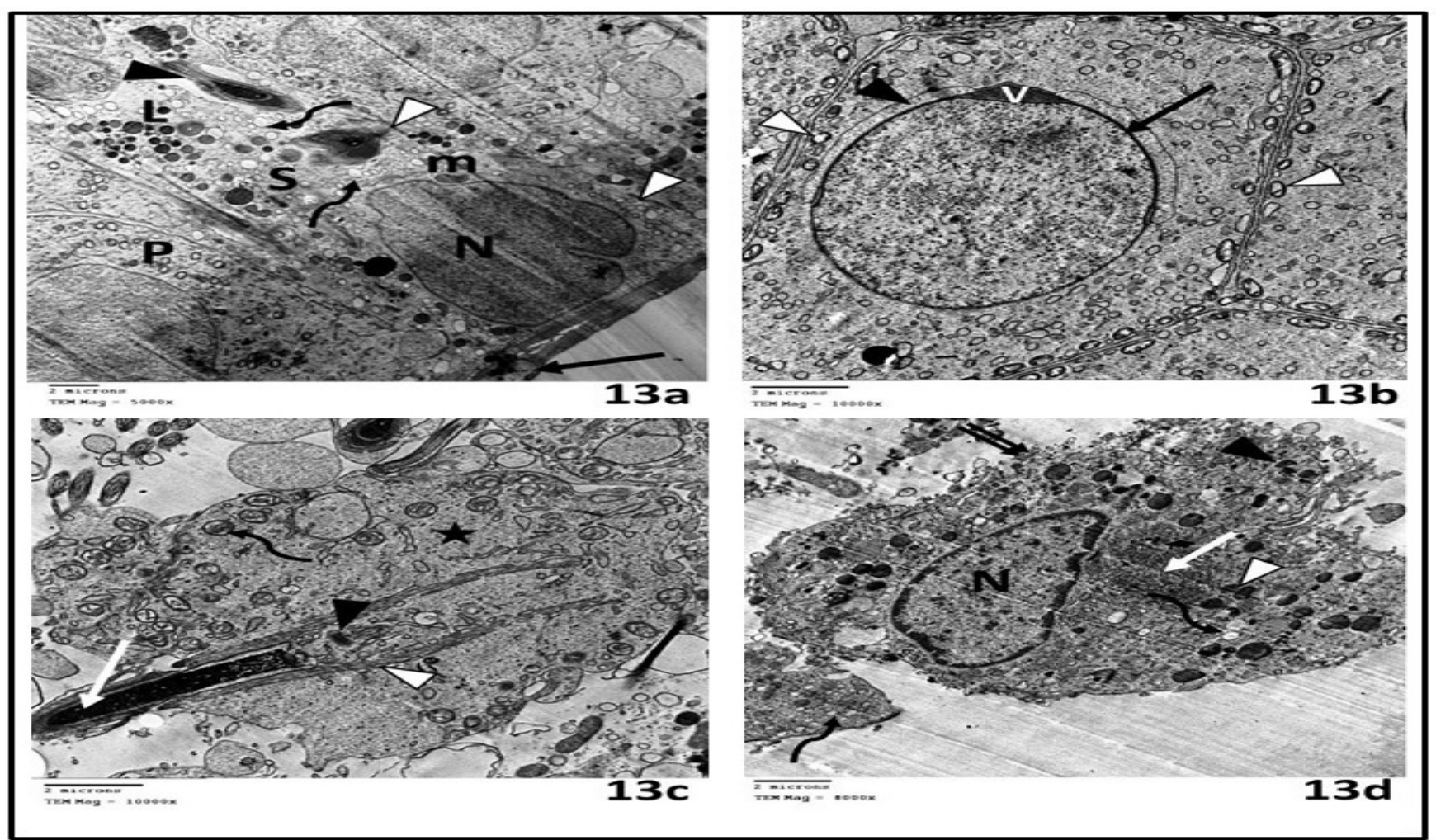

Fig. 13: Electron micrographs of control group: (13a) Columnar Sertoli cell (S) resting on a regular basement membrane surrounded by myoid cell ( $\uparrow$ ). Sertoli cell contains large pale euchromatic indented nucleus $(\mathrm{N})$. It has complex lateral and apical infoldings that house the developing gametes $(\boldsymbol{\Delta})$. Tight junctions $(\Delta)$ are seen in Sterol's lateral processes. Its cytoplasm contains smooth endoplasmic reticulum (curved arrow), mitochondria (m), and lipid droplets (L). primary spermatocyte $(\mathrm{P})$ is seen with its large nucleus. (13b) Early spermatid is seen containing large euchromatic nucleus and many peripherally arranged mitochondria with a clear matrix $(\Delta)$. Acrosomal vesicle $(\mathrm{V})$ condense and wrap around the nucleus. Large lysosome (acrosin) is seen covering the anterior portion of sperm head $(\boldsymbol{\Delta})$. The anterior two-thirds of the nucleus is covered by the acrosome ( $\uparrow)$. (13c) Maturing spermatid showing condensation of the nuclear chromatin $(\uparrow)$, excess cytoplasm $(*)$, mitochondria (curved arrow), centriole $(\boldsymbol{\Delta})$ and microtubules arising from the posterior margin of acrosmal cap forming the manchette $(\Delta)$. (13d) Interstitial Leydig cell with large euchromatic nucleus $(\mathrm{N})$ and a thin rim of peripheral dense chromatin. The cytoplasm contains smooth endoplasmic reticulum (curved arrow), mitochondria $(\Delta)$, well developed Golgi $(\uparrow)$ and numerous electron-dense lipid droplets ( $\Delta$ ). Peripheral microvilli ( $\uparrow$ ) are seen projecting from the cell membrane. TEM (13a X5000) (13b and 13c X 10000) (13d X 8000) 


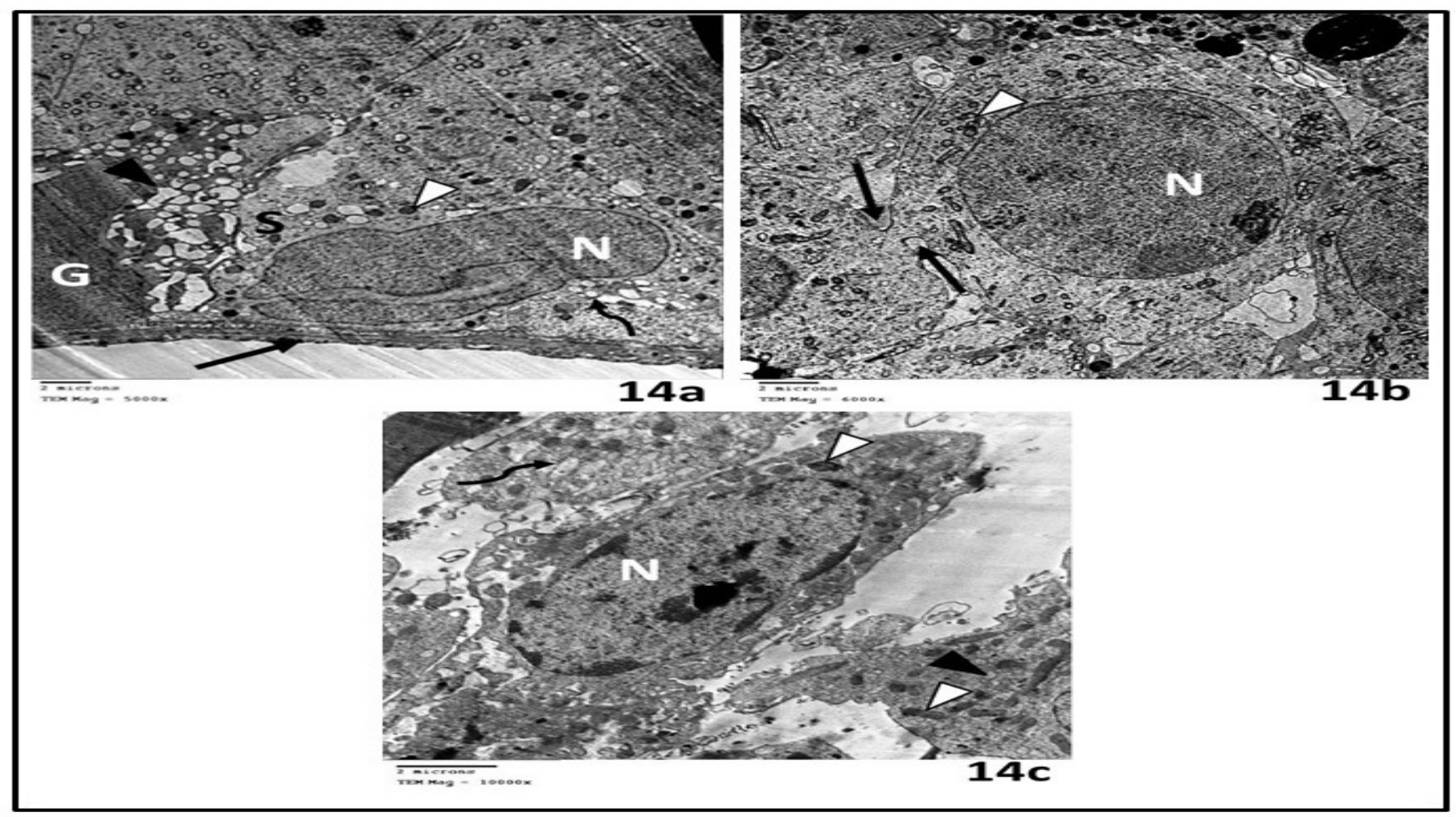

Fig. 14: Electron micrographs of single exposure group: (14a) spermatogonia (G) and Sertoli cell (S) with its large indented nucleus (N) resting on a regular basement membrane $(\uparrow)$. The cytoplasm contains mitochondria $(\Delta)$ and sER (curved arrow). Vacuolations $(\boldsymbol{\Lambda})$ are seen between the cells. (14b) nucleus of primary spermatocyte, mitochondria $(\Delta)$ and intercellular bridges $(\uparrow)$ are seen. (14c) Leydig cell with eccentric nucleus (N), mitochondria $(\Delta)$, few sER $(\mathbf{\Lambda})$ which are sometimes seen dilated (curved arrow).

TEM (a X 5000) (b X 6000) (c X 10000)

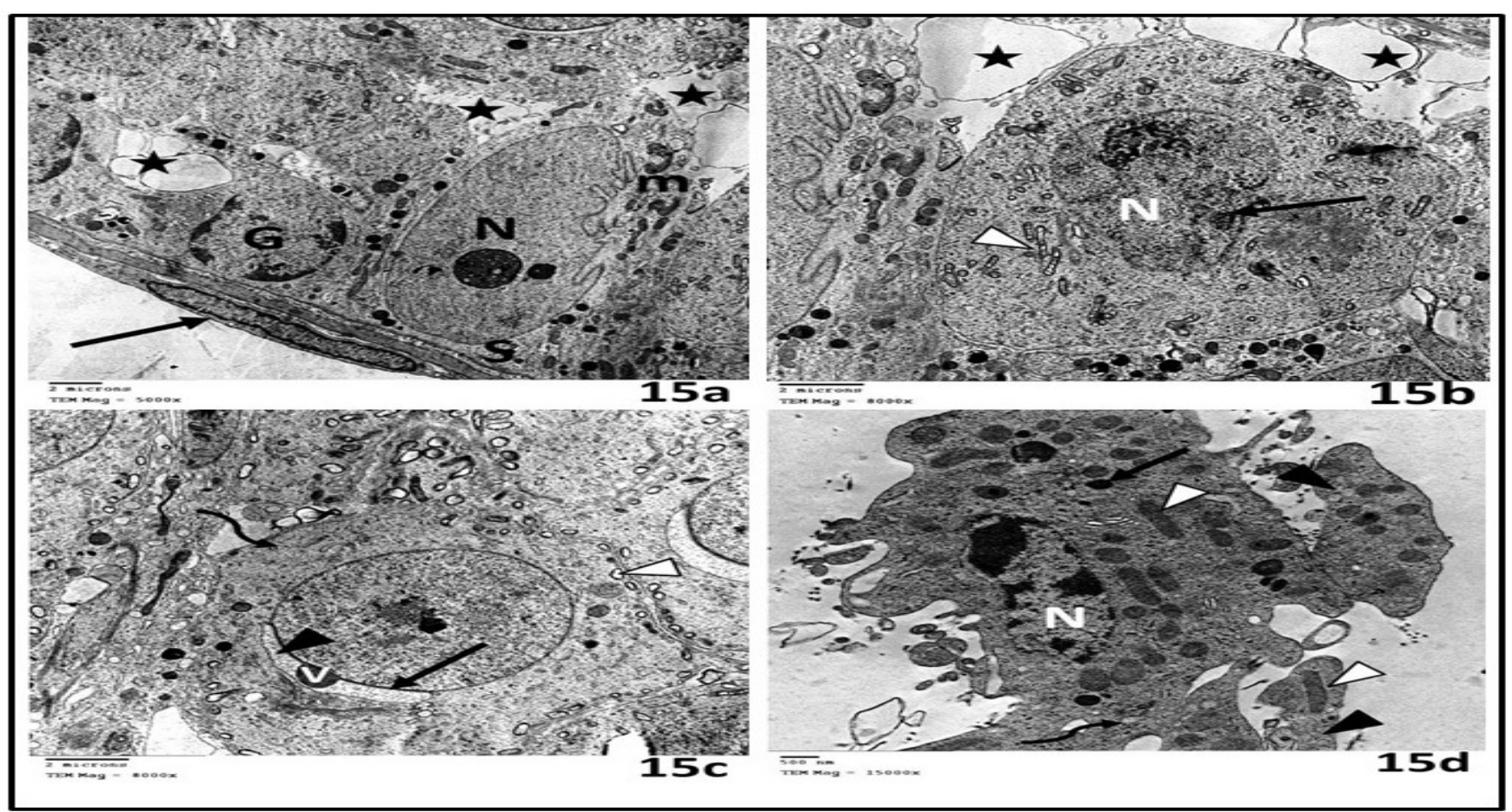

Fig. 15: Electron micrographs of multiple exposure group: (15a) spermatogonia $(\mathrm{G})$ and Sertoli cell $(\mathrm{S})$ with its large indented nucleus $(\mathrm{N})$ resting on a basement membrane surrounded by myoid cell $(\uparrow)$. Mitochondria $(\mathrm{m})$ and intercellular vacuoles $\left(^{*}\right)$ are seen. $(15 \mathrm{~b})$ distorted primary spermatocyte with irregular shrunken indented $(\uparrow)$ nucleus $(\mathrm{N})$. Elongated mitochondria $(\Delta)$ and inter-cellular vacuolation $\left.{ }^{*}\right)$. (15c) early spermatid with peripheral clear matrix mitochondria $(\Delta)$. Peripheral area of spermatid (curved arrow) with loss of peripheral arrangement of mitochondria can be seen. Acrosomal vesicle (V), acrosine lysosome $(\mathbf{\Lambda})$ and acrosome $(\uparrow)$ covering the anterior part of the nucleus are seen. (15d) Leydig cell with eccentric nucleus $(\mathrm{N})$ containing irregular arrangement of chromatin. Elongated mitochondria $(\Delta)$, sER (curved arrow) and dilated sER ( $\mathbf{\Delta})$ are seen. TEM (a X 5000) (b X 8000) (c X 8000) (d X 15000) 
Table 1: showing mean \pm SD of mean thickness of pyramidal layer in CA1 and CA3 and granule layer in dentate gyrus in different groups

\begin{tabular}{|c|c|c|c|}
\hline & \multicolumn{3}{|c|}{$\begin{array}{l}\text { Mean thickness of pyramidal } \\
\text { and granule cell layers }(\mu \mathrm{m})\end{array}$} \\
\hline & CA1 & CA3 & DG \\
\hline Control group & $62.1 \pm 8.1$ & $117.7 \pm 20.7$ & $150.7 \pm 30.6$ \\
\hline Single exposure group & $59.7 \pm 5.4^{\wedge}$ & $116.6 \pm 22.4$ & $148.9 \pm 20.4^{\boldsymbol{\Lambda}}$ \\
\hline Multiple exposure group & $47.1 \pm 4.2^{*}$ & $115.9 \pm 17.5$ & $90.6 \pm 17.9^{*}$ \\
\hline
\end{tabular}

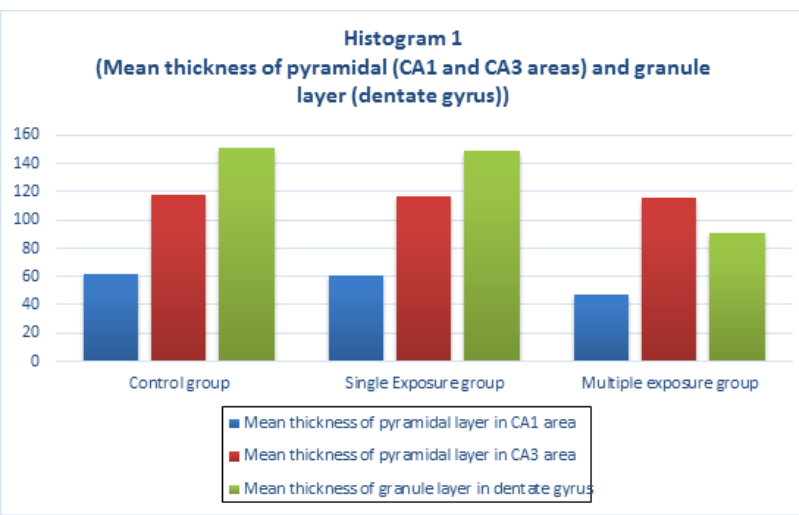

Histogram 1: showing the mean thickness of pyramidal and granule cell layers in different groups

Table 2: showing mean \pm SD of diameter of seminiferous tubule, thickness of germinal epithelium, area percentage of collagen fibers and area percentage of Caspase- 3 reaction in different groups

\begin{tabular}{|c|c|c|c|c|}
\hline & $\begin{array}{c}\text { Mean } \\
\text { diameter of } \\
\text { seminiferous } \\
\text { tubules }(\mu \mathrm{m})\end{array}$ & $\begin{array}{c}\text { Mean } \\
\text { thickness } \\
\text { of germinal } \\
\text { epithelium } \\
\quad(\mu \mathrm{m})\end{array}$ & $\begin{array}{l}\text { Mean } \\
\text { area } \% \text { of } \\
\text { collagen } \\
\text { fibers }\end{array}$ & $\begin{array}{l}\text { Mean } \\
\text { area } \% \text { of } \\
\text { Caspase-3 } \\
\text { reaction }\end{array}$ \\
\hline $\begin{array}{l}\text { Control } \\
\text { group }\end{array}$ & $254.35 \pm 42.4$ & $77.36 \pm 7.1$ & $6.29 \pm 1.3$ & $0.3 \pm 0.1$ \\
\hline $\begin{array}{l}\text { Single } \\
\text { exposure } \\
\text { group }\end{array}$ & $234.9 \pm 20.5^{*}$ & $61.37 \pm 7.2^{*}$ & $7.58 \pm 2.1^{\wedge}$ & $1.7 \pm 0.2^{\mathbf{\Delta}}$ \\
\hline $\begin{array}{l}\text { Multiple } \\
\text { exposure } \\
\text { group }\end{array}$ & $211.4 \pm 30.2^{*}$ & $51.6 \pm 5.3^{*}$ & $13.18 \pm 2.2^{*}$ & $10.1 \pm 1.3^{*}$ \\
\hline \multicolumn{5}{|c|}{ *significant change compared to all groups } \\
\hline \multicolumn{5}{|c|}{$\mathbf{\Delta}$ significant decrease compared to multiple exposure group } \\
\hline \multicolumn{5}{|c|}{$\begin{array}{c}\text { Histogram } 2 \\
\text { (Mean diameter of seminiferous tubules and mean } \\
\text { thickness of germinal epithelium) }\end{array}$} \\
\hline \multicolumn{5}{|l|}{300} \\
\hline \multicolumn{5}{|l|}{100} \\
\hline \multicolumn{2}{|c|}{ Control group } & ngle Exposuregroup & \multicolumn{2}{|c|}{ Mutiple exposure group } \\
\hline & f seminiferou & Thic & germina & \\
\hline
\end{tabular}

Histogram 2: showing mean diameter of seminiferous tubule and mean thickness of germinal epithelium in different groups

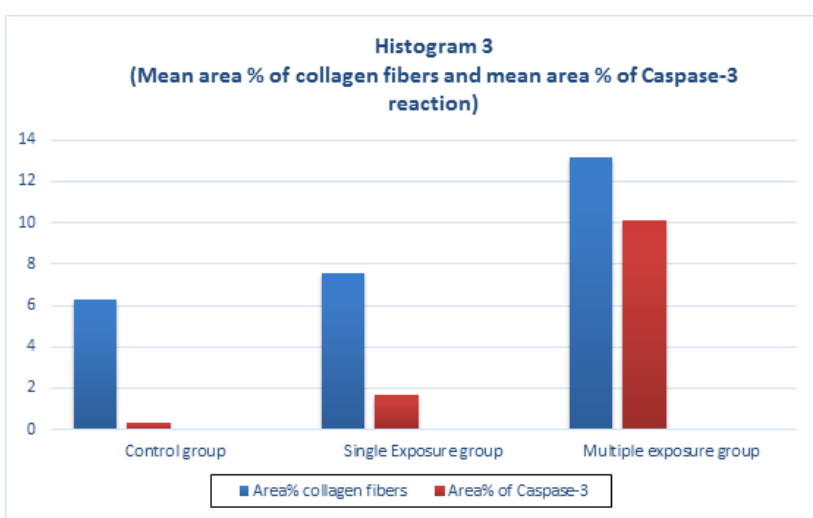

Histogram 3: showing mean area percentage of collagen fibers and mean area percentage of Caspase- 3 reaction in different groups

\section{DISCUSSION}

People are exposed to electric fields created by rapidly developing technological devices which have become a part of modern life ${ }^{[19]}$. Recently, the number of smartphone users has tremendously increased ${ }^{[2]}$; and adolescents are exposed to EMF much more frequently than ever ${ }^{[3]}$. Thus, concerns and debates regarding the effects of nonionizing radiation from smartphones on human health have emerged ${ }^{[2]}$. EMF is considered to have harmful effects on the brain and endocrine system ${ }^{[10]}$. As mobile phones are mainly caught near the brain during talking. And they are mainly kept in trousers pockets near the testis, so this study aimed to investigate effects of exposure to EMF on the structure of hippocampus and testis in adult rats.

In the current study, minimal changes were noticed in CA1, CA3 and dentate gyrus of hippocampus in single exposure group. Few cells were seen with deep basophilic cytoplasm others were with karyolitic nuclei. It was reported that neurons of hippocampus exhibit plasticity which represents the capacity of neurons to change in response to various stimuli or injury. Mature nervous tissue showed resistant to acute morphologic changes ${ }^{[6]}$.

In the current study, exposure to EMF in multiple exposure group resulted in significant decrease in pyramidal layer thickness. Similarly, it was reported that $900 \mathrm{MHz}$ EMF caused cellular losses in the total number of pyramidal cells of 4 -week-old male ${ }^{[20]}$. Others found highly significant evidence for neuronal damage in the hippocampus of exposed rats ${ }^{[21]}$. It was reported that use of $900-$ and $1800-\mathrm{MHz}$ mobile frequencies might cause formation of reactive oxygen species (ROS) in various tissues. These ROS may lead to necrosis, death of neurons and neuronal damage in brain tissue ${ }^{[2]}$. It was reported that ROS mediated oxidative damage due to high rate of oxygen consumptions, and low concentrations of antioxidants to combat oxidative stress ${ }^{[23]}$. Oxidative stress is known to be essential for pathophysiological processes in the brain, and plays important roles in the DNA damage, gene expression and cell apoptosis. The brain has a high metabolic rate, making it more prone to damage by ROS and oxidative damage compared to other organs ${ }^{[22]}$. 
Some authors noticed impaired learning, deficits of both consolidation and retrieval memory in mice exposed to $900 \mathrm{MHz}$ non ionizing radiation for 9 hours/ day for four days ${ }^{[24]}$. These observations might be due to altered structural integrity and degenerative changes in morphology of the hippocampus that was observed in the current study as an apparent decrease number of pyramidal cells in multiple exposure group. Similarly, other authors attributed alteration of spatial learning and cognitive function that were observed with prolonged exposure to $2100 \mathrm{MHz}$ mobile phone EMF, to damage and decreased number of hippocampal CA3 pyramidal neurons with change in their structural integrity ${ }^{[25]}$.

In CA3 area of multiple exposure group in the present study, some pyramidal cell nuclei were seen swollen. Decrease neuronal density and wide interstitial spaces between neurons were also noticed in some areas. It was reported that the nuclei of the neurons were more susceptible to radiation than the cytoplasm. At a low dose of radiation, the nuclear chromatin appeared somewhat clumped, swollen and edematous. At moderate to high dose of radiation, the nuclei appeared pyknotic and showed karyorrhexis ${ }^{[6]}$. They added that the probable cause of wide interstitial spaces between neurons of pyramidal cells could be due to radiation which induced endothelial damages, vasodilatation and increased vascular permeability resulting in the interstitial edema ${ }^{[6]}$. Other authors reported that decreased pyramidal cell count in hippocampus might be due to inhibition of neurogenesis ${ }^{[24]}$.

The present study also demonstrated an apparent decrease in Nissl granules in toluidine blue stained sections with increasing dose of exposure (in multiple exposure group). It was stated that Nissl bodies are a characteristic structure in hippocampal neurons. They are involved in protein synthesis, and are essential for advanced brain activities, including learning and memory ${ }^{[26]}$. Nissl bodies are strongly essential to prevent protein depletion. A decrease in the number of Nissl bodies reflects inhibition of neuronal protein synthesis. These findings suggest the toxic effects of EMF on neuronal function ${ }^{[27]}$. On the contrary, others noticed condensed Nissl granules in the cytoplasm of pyramidal cells with occasional dark stained basophil neurons in hippocampi of EMF exposed rats ${ }^{[22]}$.

Regarding the structure of testis, single exposure group of the current study showed vacuolations between spermatogenic cells, while in multiple exposure group, distorted spermatogenic cells with fragmented nuclei and significant decrease in mean diameter of seminiferous tubules were also noticed. Many studies reported that long-term $900 \mathrm{MHz}$ cell phone exposure causes decreased diameter of seminiferous tubules and height of germinal epithelium $^{[28,29]}$. However, a study by Dasdag et al. could not find any significant adverse effects of cellular phones $(1835-1850 \mathrm{MHz})$ on the rat testis ${ }^{[30]}$.

Moreover, corrugated basement membrane was noticed in some seminiferous tubules in multiple exposure group of the present study. It was reported that this finding is suggestive of necrosis, as ROS overproduction is associated with lipid peroxidation, the process in which the free radicals "steel" electrons from membrane lipids (especially polyunsaturated fatty acids), resulting in their damage ${ }^{[31]}$. Significant increase in mean area percentage of collagen fibers was also noticed in multiple exposure group of the current study. It was reported that collagens and growth factors have been implicated in the control of testicular steroidogenic function as components of extracellular matrix alter Leydig cell steroidogenesis in vitro $^{[32]}$.

Concerning Leydig cells, single exposure group of the current study showed minimal changes. While, in multiple exposure group, Leydig cells showed variable degrees of degenerative changes in the form of clumped nuclear chromatin, dilated sER and elongated mitochondria.

It was stated that testosterone hormone is essential for spermatogenesis and production of spermatozoa. Exposure to mobile phones causes damage via oxidative stress. This might cause deformation and apoptosis of Leydig cells with subsequent spermatogenic dysfunction and change in the sperm cell cycle ${ }^{[29,33]}$. Similarly, it was reported that continuous exposure to EMF induced apoptosis of spermatogenic cells in a duration and dose dependent manner ${ }^{[10,34]}$. In the current study, apoptosis was noticed in some Leydig cells in single exposure group which was increased in multiple exposure group. It was reported that caspase is cysteinyl aspartate specific proteinases. These enzymes cleave multiple protein substrates, leading to the loss of cellular structure and function and ultimately resulting in cell death. Generally, two pathways are suggested for apoptosis: the intrinsic pathway which is mitochondrial-dependent and extrinsic pathway which is cell-surface death receptor dependent. Extrinsic pathway is triggered by binding of the tumor necrosis factor- $\alpha$ on their special receptors on the cell membrane. Activation of these receptors causes activation of intracellular caspases with subsequent DNA degradation. Intrinsic pathway is triggered by cell stress factors as irradiation, toxins and oxidative stress. These stress sources destabilize the mitochondrial membrane ${ }^{[35]}$. Other authors reported that apoptosis might be induced by the stress of endoplasmic reticulum, which is mainly induced by a reduction in intraluminal free-calcium concentration ${ }^{[34]}$. Also, ROS cause DNA fragmentation and protein degradation leading to cell apoptosis ${ }^{[31]}$.

Regarding semen analysis, many sperm abnormalities were noticed in single and multiple exposure group. It was reported that sperm cells which had broken head, or that lacked hook-shaped heads (headless), or had their tails bent toward the head were considered abnormal[ ${ }^{[36]}$. On the contrary, another study showed a normally developed histological image of the testis and sperm analysis of irradiated animals. The exposed group exhibited complete spermatogenesis, numerous spermatozoa, a germinal epithelium of regular height, and a tubular lumen of normal diameter ${ }^{[37]}$. This discrepancy might be because they 
exposed rats to $915 \mathrm{MHz}$, and their experiment lasted only for two weeks. Which might suggest that decrease sperm parameters depends on the duration of daily exposure. It was reported that the duration of cell phone use was negatively correlated with the proportion of motility and rapid progressive motile spermatozoa ${ }^{[10]}$.

In the current study, ultrastructure examination of multiple exposure group, revealed distorted primary spermatocytes, disturbed mitochondrial arrangement in early spermatids and intercellular vacuoles. It was reported that electric and magnetic fields negatively affect electron flow through the inner membrane of the cell with subsequent disturbance of cellular and organelle functions ${ }^{[19]}$. Some authors have shown that EMFs penetrate living organisms and alter the cell membrane potential. This alteration may affect free-radical processes within the cell and alter the activities of antioxidant enzymes. EMF has a negative effect on testicular function through the induction of oxidative stress and the concomitant disruption of the testicular antioxidant status ${ }^{[28]}$. They suggested that EMF may change the permeability of the blood-testis barrier. It was reported that EMF-mediated ROS formation which lead to heat shock protein production and phosphorylation. This can alter the secretion of growth factors and mediate an increase in the blood-testis barrier permeability ${ }^{[38]}$.

The changes observed during histological examination in the current study, gave the impression that significant changes might occur if the study period were to be extended. Longer studies are needed to better understand the effects of EMFs on testis tissue.

\section{CONCLUSIONS}

Exposure to EMF causes significant changes in the structure of hippocampus and testis in a dose dependent manner.

\section{RECOMMENDATIONS}

It is recommended to use head phones during talking in mobile phones to avoid proximity to brain hippocampus that has an important role in cognitive functions. Adolescence should also avoid carrying mobile phones in their trousers' pocket to minimize exposure of testis to EMF.

\section{CONFLICTS OF INTEREST}

There are no Conflicts of Interest

\section{REFERENCES}

1. Bahaodini A, Owjfard M, Tamadon A, Jafari SM. Low frequency electromagnetic fields long-term exposure effects on testicular histology, sperm quality and testosterone levels of male rats. Asian Pacific Journal of Reproduction 2015; 4(3): 195-200

2. Choi Y-J, Choi Y-S. Effects of Electromagnetic Radiation from Smartphones on Learning Ability and Hippocampal Progenitor Cell Proliferation in Mice, Osong Public Health Res Perspect 2016, 7(1):12-17
3. Zhang JP, Zhang KY, Guo L, Chen QL, Gao P, Wang T, Li J, Guo GZ and Ding GR. Effects of $1.8 \mathrm{GHz}$ Radiofrequency Fields on the Emotional Behavior and Spatial Memory of Adolescent Mice. Int. J. Environ. Res. Public Health 2017, 14, 1344.

4. Genuis SJ. Fielding a current idea: exploring the public health impact of electromagnetic radiation. Public Health 2008; 122: 113e24. Review.

5. Oyewopo AO, Olaniyi SK, Oyewopo CI, Jimoh AT. Radiofrequency electromagnetic radiation from cell phone causes defective testicular function in male Wistar rats. Andrologia. 2017; 49(10). doi: 10.1111/ and. 12772 .

6. Mugunthan N, Shanmugasamy K, Anbalagan J, Rajanarayanan S, Meenachi S. Effects of LongTerm Exposure of 900-1800 MHz Radiation Emitted from 2G Mobile Phone on Mice Hippocampus- A Histomorphometric Study. J Clin Diagn Res. 2016; 10(8):AF01-6.

7. George MJ and Odgers CL. Seven Fears and the Science of How Mobile Technologies May Be Influencing Adolescents in the Digital Age. Perspect Psychol Sci. 2015; 10(6):832-51.

8. Kwan RY and Lai CK. Can smartphones enhance telephone- based cognitive assessment (TBCA)? Int J Environ Res Public Health. 2013; 10 (12):7110-25.

9. Soliman NB and Shoukry Y. Effect of cyclic versus continuous hormonal replacement therapy on the structure of dentate gyrus of ovariectomized adult albino rats: a histological and immunohistochemical study. Egypt J Histol. 2014; 37:339-349

10. Oh JJ, Byun SS, Lee SE, Choe G, and Hong SK. Effect of Electromagnetic Waves from Mobile Phones on Spermatogenesis in the Era of 4G-LTE Hindawi BioMed Research International 2018; 2018:1801798: 8 pages.

11. Çetkin M, Kızılkan N, Demire C, Bozdağ Z, Erkılıç S, Erbağc H. Quantitative changes in testicular structure and function in rat exposed to mobile phone radiation. Andrologia. 2017; 49: e12761.

12. Peter AV, Emilie VD and Michael HR. Workgroup report: Base stations and wireless networksradiofrequency (RF) exposures and health consequences. Environ. Health Perspect 2007; 115: 416-424.

13. Dasdag S., Akdag M.Z., Aksen F., Bashan M. and Buyukbayram H. Does $900 \mathrm{MHz}$ GSM mobile phone exposure affect rat brain? Electromagn. Biol. and Med. 2004; 23(3): 201-214.

14. Heym $\mathrm{CH}$, Forssman WG. Techniques in neuroanatomical research. Springer verlag, Berlin, Heidelberg and New York. 1981, pp:3-9. 
15. Scudamore CL. A practical guide to the histology of the mouse. 1st edition. Wiley Blackwell. John Wiley and Sons, Ltd. Laser words private, Chennai, India, 2014. p:17- 18 .

16. Suvarna K, Layton C, Bancroft J. Theory and practice of histological techniques. 7th ed. USA: Churchill Livingston; 2013

17. Agarwal A, Gupta S and Sharma R. Andrological evaluation of male infertility. A laboratory Guide. 2016. Springer international Switzerland. Cleveland USA. P:73-78

18. Raafat MH and Hamam GG. The possible protective role of royal jelly against cisplatininduced testicular lesions in adult albino rats: a histological and immunohistochemical study. The Egyp. J Histology; 2012, 35:353-365

19. Aslankoc R, Gumral N, Saygin M, Senol N, Asci H, Cankara FN, Comlekci S. The impact of electric fields on testis physiology, sperm parameters and DNA integrity-The role of resveratrol. Andrologia. 2018; 6 . doi: 10.1111/and.12971

20. Erdem Koç G, Kaplan S, Altun G, Gümüş H, Gülsüm Deniz Ö, Aydin I, Emin Onger M, Altunkaynak Z. Neuroprotective effects of melatonin and omega-3 on hippocampal cells prenatally exposed to $900 \mathrm{MHz}$ electromagnetic fields. Int $\mathrm{J}$ Radiat Biol. 2016; 92(10):590-5

21. Salford LG, Brun AE, Eberhardt JL, Malmgren L and Persson PRR. Nerve Cell Damage in Mammalian Brain after Exposure to Microwaves from GSM Mobile Phone. Environmental Health Perspectives 2003; 111(7): 881-883.

22. Kivrak EG, Altunkaynak BZ, Alkan I, Yurt KK, Kocaman A, Onger ME. Effects of 900-MHz radiation on the hippocampus and cerebellum of adult rats and attenuation of such effects by folic acid and Boswellia sacra. Journal of Microscopy and Ultrastructure 2017; 5: $216-224$

23. Ikonomidou $\mathrm{C}$ and Kaindl AM. Neuronal death and oxidative stress in the developing brain. Antioxid. Redox Signal. 2011; 14, 1535-1550.

24. Kishore KG, Venkateshu KV, Sridevi NS. Effect of 1800-2100 MHz Electromagnetic Radiation on Learning-Memory and Hippocampal Morphology in Swiss Albino Mice. Journal of Clinical and Diagnostic Research. 2019; 13(2): AC14-AC17

25. Kishore GK, Venkateshu KV, Sridevi NS. Effects of 1800-2100 MHZ mobile phone electromagnetic radiation on mice hippocampal CA3 neurons. Int J of scientific research. 2018; 7(11): 682-684

26. Cheng O, Ostrowski RP, Liu W, and Zhang JH. "Activation of Liver X Receptor Reduces Global Ischemic Brain Injury by Reduction of Nuclear Factor-
Kb." Neuroscience 2010; 166(4): 1101-09.

27. Lai S, Gu Z, Zhao M, Li X, Ma Y, Luo L, and Liu J. "Toxic Effect of Acrylamide on the Development of Hippocampal Neurons of Weaning Rats." Neural regeneration research 2017; 12(10): 1648.

28. Al-Damegh MA. Rat testicular impairment induced by electromagnetic radiation from a conventional cellular telephone and the protective effects of the antioxidants vitamins C and E. Clinics 2012; 67(7): 785-792

29. Sehitoglu I, Tumkaya L, Kalkan Y, Bedir R, Cure MC, Zorba OU, Cure E and Yuce S. Biochemical and histopathological effects on the rat testis after exposure to electromagnetic field during fetal period. Arch. Esp. Urol. 2015; 68 (6): 562-568

30. Dasdag S, Akdag MZ, Ulukaya E, Uzunlar AK, Yegin D. Mobile phone exposure does not induce apoptosis on spermatogenesis in rats. Arch. Med. Res. 2008;39(1):40-4,

31. Atalla SS, Saleh HA, Abdel Gawad S and Mohamed H. Histological study on the effect of adipose tissuederived mesenchymal stem cells on the testis of chemically induced castration model by calcium chloride in adult albino rats. Egyp. J of Histology 2017; 40(4):486-496

32. Zhu C-c, Tang B, Su J, Zhao H, Bu X, Li Z, Zhao J, Gong W, Wu Z, Yao L, Li W, Zhang Y. Abnormal Accumulation of Collagen Type I Due to the Loss of Discoidin Domain Receptor 2 (Ddr2) Promotes Testicular Interstitial Dysfunction. PLoS ONE 2015; 10(7): e0131947

33. Kesari KK, Kumar S, Behari J. Effect of radiofrequency electromagnetic wave exposure from cellular phones on the reproductive pattern in male Wistar rats. Applied Biochemistry and Biotechnology, 2011; 164, 546-559

34. Saygin M, Caliskan S, Karahan N, Koyu A, Gumral N, and Uguz AC. Testicular apoptosis and histopathological changes induced by a $2.45 \mathrm{GHz}$ electromagnetic field. Toxicology and Industrial Health; 2011; 27(5) 455-463

35. Fadeel B and Orrenius S. Apoptosis: a basic biological phenomenon with wide-ranging implications in human disease. Journal of Internal Medicine 2005; 258: 479-517.

36. Trosic I, Matausic-Pisl M, Pavicic I and Marjanovic MA. histological and cytological examination of rat reproductive tissue after short-time intermittent radiofrequency exposure. Arh Hig Rada Toksikol 2013; 64:513-519

37. Deepinder F, Makker K, Agarwal A. Cell phones and male infertility: dissecting the relationship. Reprod Biomed Online 2007; 15: 266-70. 
38. Desai NR, Kesari KK, Agarwal A. Pathophysiology of cell phone radiation: oxidative stress and carcinogenesis with focus on male reproductive system. Review Reprod Biol Endocrinol. 2009; 7:114. 


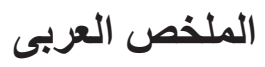

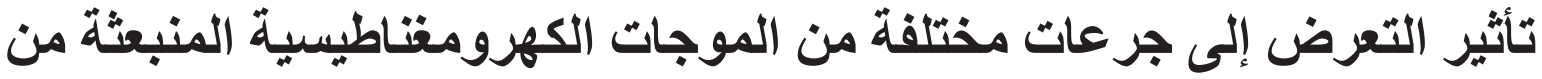

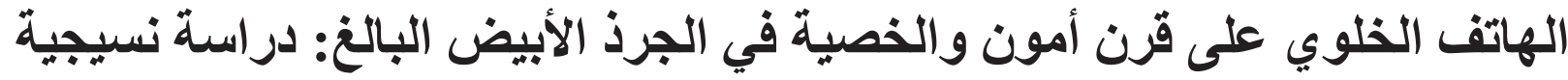

\section{باتعة محمد علي الكافوري'، غادة جلال حمامّ وسمر فكري عزت׳}

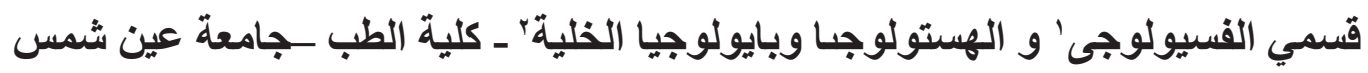

المقدمة: إن كل منتج جديد من منتجات التكنولوجيا يجلب العديد من المساوئ التي تهدد صحة الانسان. فالمجال الكهرومغناطيسي المنبعث من التليفون الخلوي قد يكون له ناثير ات ضارة على صحة الإنسان و قد يؤثر على اجهزته الإدر اكية و التناسلية. يتم حمل الهو اتف المحمولة بثكل أساسي بالقرب من الر أس أثناء التحدث كما يتم الاحتفاظ بها أيضًا في جيوب البنطال على مقربة من الخصية. الهدف من البحث: هو دراسة تعرض الجسم لجرعات مختلفة من المجال الكهرومغناطيسي المنبعث من التليفول المحمول على نسيج قرن أمون و الخصية في ذكور الجرذان الويستار البيضاء. المواد والطرق: تم تقسيم ثلاثين من الجرذان الويستار المهق إلى ثلاث مجموعات متساوية. المجموعة الأولى ته تم استخدامها كمجموعة ضابطة. المجموعة الثانية (تم تعريض الجرذان لأشعة هاتف خلوي واحد . .9 هيرتز). المجمو عة الثالثة (تم تعريض الجرذان لأشعة ثلاثة هو اتف محمولة . . FV هيرتز) . وقد تم تعريض الجرذان للموجات

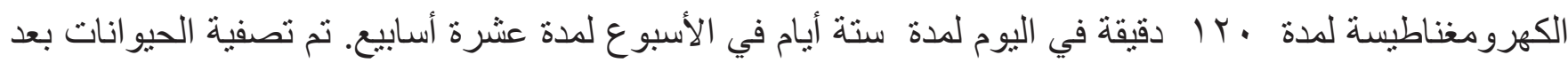
مرور 24 ساعة من اخر تعرض للموجات الكهرومغناطيسية. ولقد تم تجميع قرن امون والخصي من كل الجرذان و إعدادهما للار اسات الهستولوجية المناسبة. كما تم عمل تحليل للسائل المنوي ودر اسات إحصائية للنتائج. النتائج: لوحظ وجود ضمور في بعض الخلايا الهرمية و الخلايا المحببة لقرن امون، في المجموعة التي تعرضت لأشعة هاتف محمول واحد. كما شو هدت تجويفات بين الخلايا المولدة للمني مع إعنلال في تركيب الحيوان المنوي. ولكن في المجموعة التي تعرضت أثنعة عدة هو اتف محمولة فلقد لوحظ وجود زيادة ظاهرية في عدد الخلايا العصبية التالفة مع نقصان ذو دلالة إحصائية و اضحة في سمك الطبقتين الهرمية و المحبية لقرن امون. بينما أظهرت الخصية وجود تجويفات ما بين الخلايا و نقصان ذو دلالة إحصائية واضحة في سمك الظهارة الإنتاثية والقنوات ناقلة المني مع زيادة ذات دلالة إحصائية واضحة في النسبة المئوية لمتوسط مساحة ألياف الكو لاجين وتفاعل الكاسبيز كما لوحظ وجود الكثير من التشوهات في الحيو انات المنوية عند تحليل السائل المنوي. الإستنتاج: إن التعرض للمجال الكهرومغناطيسي يؤدي إلى تغيرات واضحة في تركيب قرن أمون و الخصية بطريقة معتمدة على جر عة الأشعة المتعرض لها. 